\title{
Well Blowout Rates and Consequences in California Oil and Gas District 4 from 1991 to 2005: Implications for Geological Storage of Carbon Dioxide
}

\author{
Preston D. Jordan and Sally M. Benson \\ P. D. Jordan (\&) \\ Earth Sciences Division, Lawrence Berkeley National \\ Laboratory, Berkeley, CA 94720, USA \\ e-mail: pdjordan@lbl.gov \\ S. M. Benson \\ Department of Energy Resources Engineering, \\ Stanford University, Stanford, CA 94305, USA
}

\begin{abstract}
Well blowout rates in oil fields undergoing thermally enhanced recovery (via steam injection) in California Oil and Gas District 4 from 1991 to 2005 were on the order of 1 per 1,000 well construction operations, 1 per 10,000 active wells per year, and 1 per 100,000 shutin/idle and plugged/abandoned wells per year. This allows some initial inferences about leakage of CO2 via wells, which is considered perhaps the greatest leakage risk for geological storage of CO2. During the study period, $9 \%$ of the oil produced in the United States was from District 4 , and $59 \%$ of this production was via thermally enhanced recovery. There was only one possible blowout from an unknown or poorly located well, despite over a century of well drilling and production activities in the district. The blowout rate declined dramatically during the study period, most likely as a result of increasing experience, improved technology, and/or changes in safety culture. If so, this decline indicates the blowout rate in CO2-storage fields can be significantly minimized both initially and with increasing experience over time. Comparable studies should be conducted in other areas. These studies would be particularly valuable in regions with $\mathrm{CO} 2$-enhanced oil recovery (EOR) and natural gas storage.
\end{abstract}

Keywords: geological carbon dioxide storage, thermally enhanced oil recovery, well leakage, well blowout, California

\section{Introduction}

Migration up abandoned and active wells is considered to pose perhaps the greatest risk of leakage for geological storage of $\mathrm{CO}_{2}$ (Gasda et al. 2004; Benson et al. 2005). Well blowouts are formally defined as "the uncontrolled flow of well fluids and/or formation fluids from the well bore to the surface (surface blowout), or into lower-pressured subsurface zones (underground blowout; Hauser and Guerard 1993).'” The "'Underground geological storage" chapter in the IPCC special report on carbon dioxide capture and storage (Benson et al. 2005) concluded that the local risks of geological $\mathrm{CO}_{2}$ storage would be similar to existing activities. Specifically, the IPCC report stated

With appropriate site selection informed by available subsurface information, a monitoring program to detect problems, a regulatory system, and the appropriate use of remediation methods to stop or control $\mathrm{CO}_{2}$ releases if they arise, the local health, safety and environment risks of geological [CO 2$]$ storage would be comparable to risks of current activities such as natural gas storage, EOR, and deep underground disposal of acid gas.

When the IPCC special report was completed, a systematic, quantitative assessment of risks associated with the so-called industrial analogs for geological storage, such as natural gas storage and $\mathrm{CO}_{2}$-enhanced oil recovery (EOR), had not been undertaken. Similarly, a literature 
search did not find studies of blowout frequency in the peer-reviewed literature of the last decade. Therefore, this study was undertaken to gain a better understanding of the risks of well blowouts in the oil industry-one type of event which sometimes results in local health, safety, and environmental impacts-and discuss the relevance of this understanding to geologic $\mathrm{CO}_{2}$ storage.

This paper analyzes the frequency and, more generally, the consequences of surface blowouts occurring in Oil and Gas District 4 in California from 1991 to 2005. The goal of this study is to gain perspective on leakage of $\mathrm{CO}_{2}$ from storage fields to the surface via wells. The majority of District 4's oil production was by thermally enhanced recovery, which involves injecting large quantities of steam. While District 4 wells experience different pressure, thermomechanical, and chemical conditions than expected for wells in future $\mathrm{CO}_{2}$-storage fields, analysis of blowouts from District 4 wells provides useful insights and comparisons from which to begin to assess the probability for leakage of $\mathrm{CO}_{2}$ to the surface via wells, and the potential consequences of this leakage.

\section{Background}

\section{Oil production from District 4}

The location of California Oil and Gas District 4 is shown in Fig. 1. Oil production in the district dates back to the late 1800s (San Joaquin Geological Society 2007). All of the oil fields in Kern County occur in the southern San Joaquin Valley, which is located between the southern extent of the Coast Ranges and the Sierra Nevada. Nearly all of these fields are in the western half of Kern County, as shown in Fig. 2.

California was third among the states in total oil production for the 1991-2005 period (Energy Information Administration 2007). Statistics for oil production in District 4 from 1991 to 2005 are provided in Table 1 and Fig. 3, showing that District 4 is a prolific oil and gas producer (California Division of Oil, Gas and Geothermal Resources 1992-2006; Energy Information Administration 2007). Approximately three quarters of the oil production wells in California (excluding the Federal offshore wells) are located in District 4. Three-fifths of the oil produced in District 4 results from thermal recovery via steam injection. Steam injection occurred during part or all of the study period in 17 of the approximately 80 oil fields in the district. Among these fields are four of the five largest in the district and five of the ten largest in the state. Because of its size and the predominance of thermal oil recovery via steam injection, District 4 provides a significant area for analysis of blowouts in general and blowouts associated with fluid injection in particular.
Like other flooding methods, steam injected during thermally enhanced recovery provides an increased pressure drive for production of oil. In addition, the steam heats the oil and thus lowers its viscosity, which enhances flow during production. The steam also causes distillation of the lighter oil fractions. These lighter fractions condense ahead of the steam front, dissolving some of the residual oil, which further promotes flow. The two predominant methods of thermally enhanced recovery are cyclic-steam injection and steam flooding. In cyclic-steam injection, steam is injected for a short time period, and then the well is shut in to allow the previously injected steam to heat the formation and oil. The well is subsequently placed on production to recover the liberated oil, and then returned to steam injection to repeat the process. In steam flooding, steam is continually injected into one set of wells while oil is produced from interspersed wells.

The average spatial density for all active wells, and for steam-injection wells, in thermal fields during the study period was 104 and 28 per square kilometer $\left(\mathrm{km}^{2}\right)$ [269 and 73 per square mile $\left(\mathrm{mi}^{2}{ }^{2}\right)$ ], respectively. This corresponds to an average well spacing of 98 and $189 \mathrm{~m}$ (321 and $620 \mathrm{ft}$ ) assuming a square well pattern. The average density for all active wells ranged from 1 to 244 wells $/ \mathrm{km}^{2}$ (3633 wells $/ \mathrm{mi}^{2}{ }^{2}$ ), and from $<0.1$ to 98 wells $/ \mathrm{km}^{2}(<0.26-$ $255 / \mathrm{mi}^{2}{ }^{2}$ ) for steam-injection wells on a per-thermal-field basis. These densities correspond to an average well spacing of 1,000-64 m (3,290-210 ft) for all wells and $>10,000-101 \mathrm{~m} \quad(>32,800-331 \mathrm{ft})$ for steam-injection wells.

\section{Demographics and land use in District 4}

Approximately two-thirds of the cities in the San Joaquin Valley portion of Kern County are underlain at least in part by oil fields, as shown in Fig. 2 . The population density in Kern County was 36 persons $/ \mathrm{km}^{2}$ (93 persons $/ \mathrm{mi}^{2}$ ) in 2000 (US Census Bureau 2007). The population density in western Kern County varied from $\sim 0$ to 7,000 persons/ $\mathrm{km}^{2}\left(\sim 0-18,000\right.$ persons $\left./ \mathrm{mi}^{2}{ }^{2}\right)$ as shown in Fig. 4. Oil fields underlie the full range of population densities, but fields with steam injection underlie population densities ranging from 0 to 1,000 persons $/ \mathrm{km}^{2}(0-2,500$ persons/ $\mathrm{mi}^{2}{ }^{2}$. Most fields, both with and without steam injection, underlie areas with population densities between 0 and 4 persons $/ \mathrm{km}^{2}$ ( 0 and 10 persons $/ \mathrm{mi}^{2}$ ).

The predominant land use in the San Joaquin Valley portion of Kern County is irrigated agriculture, as shown in Fig. 5. The second most predominant land use is open land, shown as "Native classes" in Fig. 5. Such lands are used for a variety of non-irrigated purposes, such as range land. The least predominant land use is urban. Oil fields underlie all three land-use types. The largest fields, as well as most 


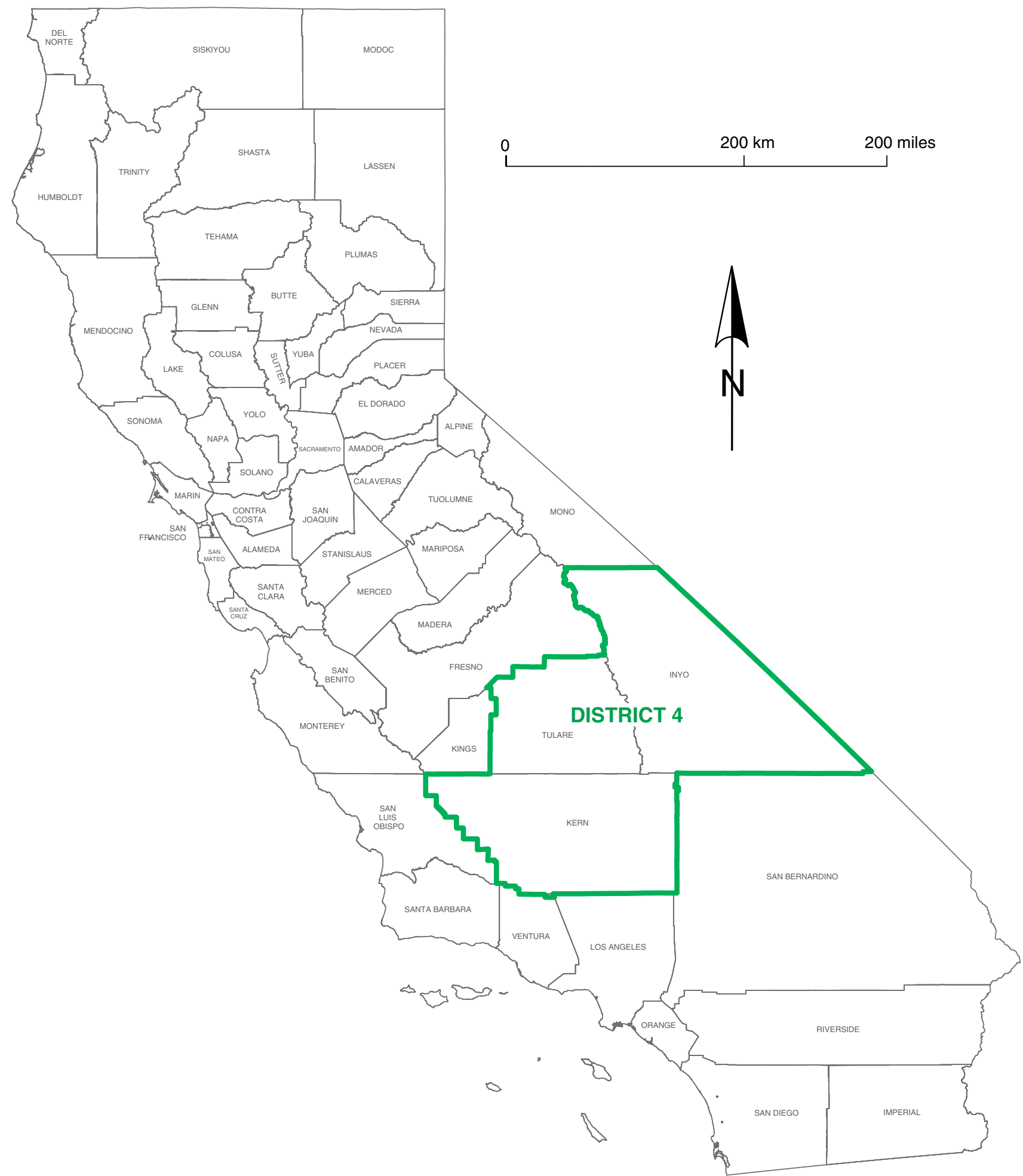

Fig. 1 Location of California Oil and Gas District 4 (courtesy of the California Division of Oil, Gas and Geothermal Resources)

of the fields with steam injection, underlie open lands. Note that the urban land use shown for the fields near Lost Hills is for extractive industries, not residential areas, and does not represent population centers.
Common causes of well blowouts

Well blowouts occur both during work on a well and during well operation. Typical well work includes drilling, 
Fig. 2 Cities and towns in western Kern County, and all District 4 oil fields with steam injection-well density for each field (adapted from Kern Council of Governments undated and California Division of Oil, Gas and Geothermal Resources 2002)

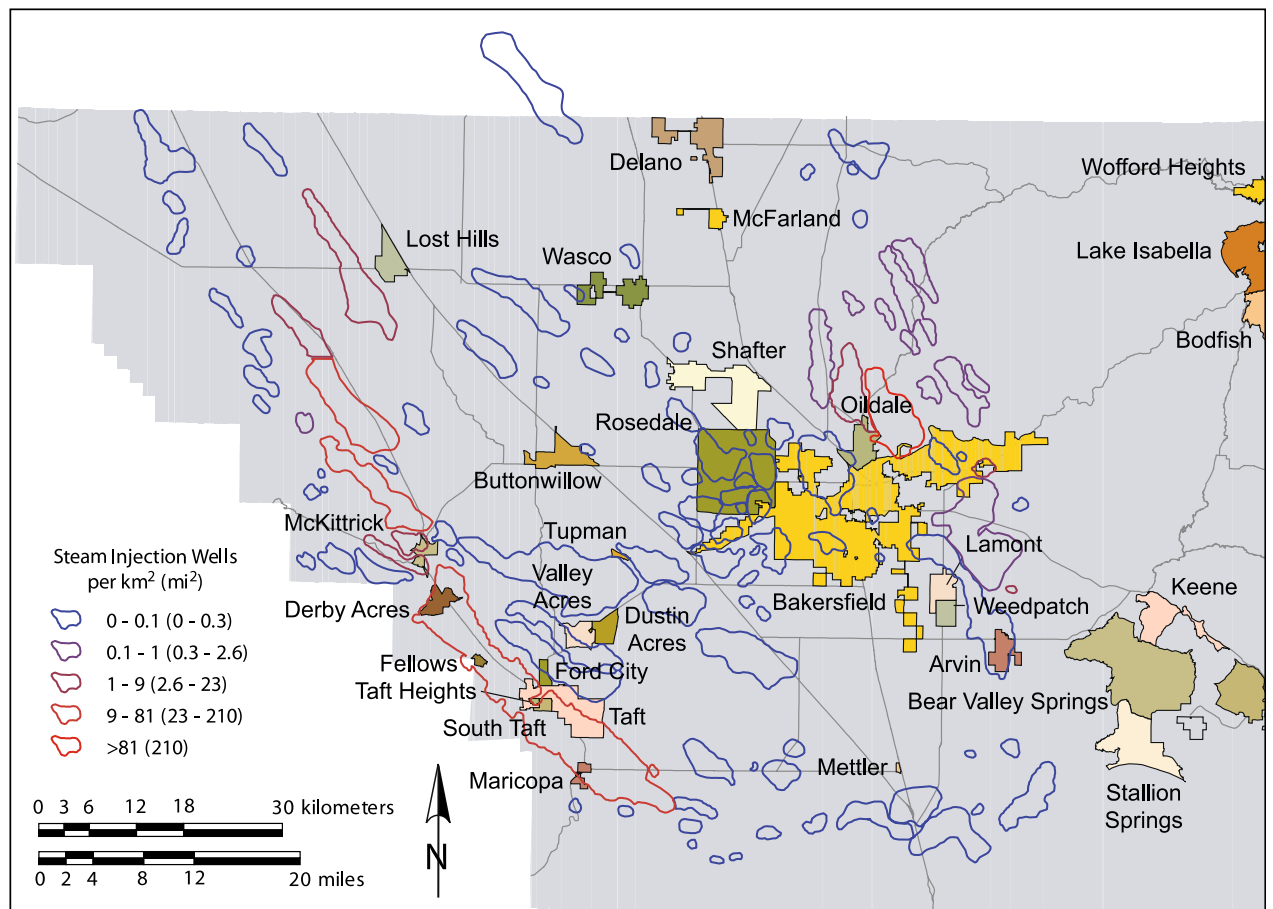

Table 1 Summary of California and District 4 statistics on oil production and steam injection, and total number of producing and steaminjection wells

\begin{tabular}{llll}
\hline & California & District 4 & District 4 as \% of California \\
\hline Oil production $\left[\mathrm{m}^{3}\right.$ (bbl) in millions] & $654(4,116)$ & $493(3,101)$ & 75 \\
Thermally enhanced oil production [m $^{3}$ (bbl) in millions] & $328(2,061)$ & $296(1,858)$ & 90 \\
Portion of oil production due to thermally enhanced recovery $\%$ ) & 50 & 60 & - \\
Total steam injected [liquid equivalent, $\mathrm{m}^{3}$ (bbl) in millions] & $1,279(8,044)$ & $1,109(6,973)$ & 87 \\
Water production [m ${ }^{3}$ (bbl) in millions] & $5,079(31,947)$ & $2,859(17,984)$ & 56 \\
Oil production wells & 46,015 & 35,186 & 76 \\
Steam-flood injection wells & 4,561 & 4,053 & 89 \\
Cyclic-steam wells & 9,408 & 9,013 & 96
\end{tabular}

Fluid volumes are 1991-2005 totals and well totals are 1991-2005 annual averages (DOGGR 1992-2006)

completion, servicing, reworking (also called work over), and plugging and abandoning. Well completion operations typically consist of lowering casing into the well, cementing the annulus, and perforating the casing to provide a connection to the reservoir. Well servicing includes a range of activities, such as the replacement of production tubing and downhole equipment (pumps and rods, for instance), collection of wireline logs, perforating casing and squeeze cementing prior perforations. Rework (work over) operations include activities such as cleaning out sand, repairing liners and/or casing, and deepening a well. Plugging and abandoning operations include removing casing and plugging wells at various depths with cement (Occupational Safety and Health Administration 2007).

Blowouts during these operations usually occur due to (1) failure to maintain a sufficiently dense drilling fluid to control downhole pressures, (2) failure to keep the boring full of drilling fluid, and (3) swabbing in formation fluids (Hauser and Guerard 1993). Swabbing refers to creation of a low-pressure zone resulting from too-rapid vertical movement of tight fitting tools or well components. This low-pressure zone can cause relatively lower density formation fluids to enter the well bore, which lowers the hydrostatic pressure in the bore. This, in turn, can cause more formation fluid to enter. This positive feedback loop can rapidly unload the drilling fluid from a bore and cause a blowout if the surface blowout-prevention equipment fails (Schlumberger 2007).

Blowouts also occur from wells on production or injection or wells that are shut-in/idle or abandoned. These blowouts typically occur due to failure of some well component, either as a result of aging, such as well-casing 
Fig. 3 Thermal oil production in California Oil and Gas District 4 between 1991 and 2005 compared to District 4, California, and United States total oil production (California Division of Oil, Gas and Geothermal Resources 19922006; Energy Information Administration 2007)

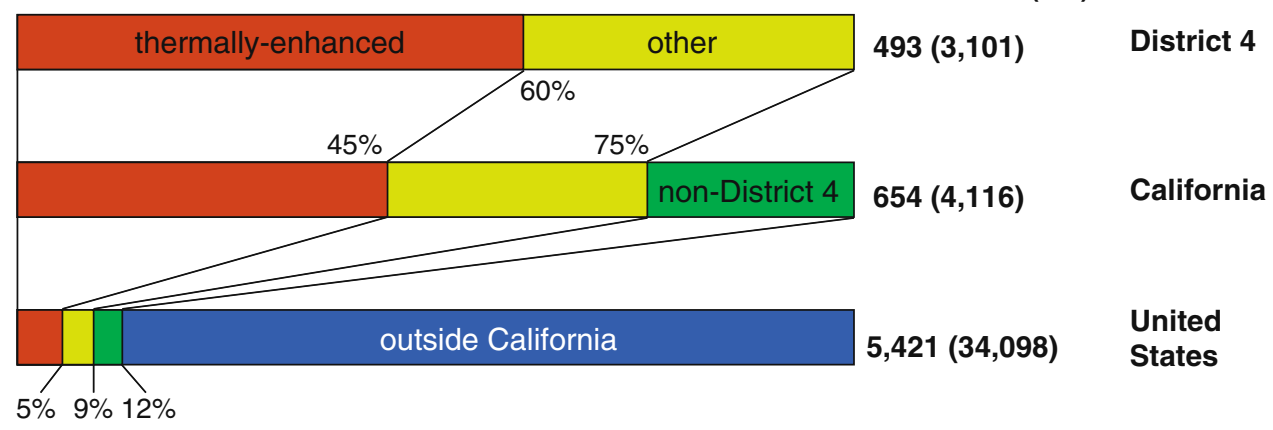

Fig. 4 District 4 oil fields and western Kern County population density by block group in 2000 (United States Census Bureau 2007)

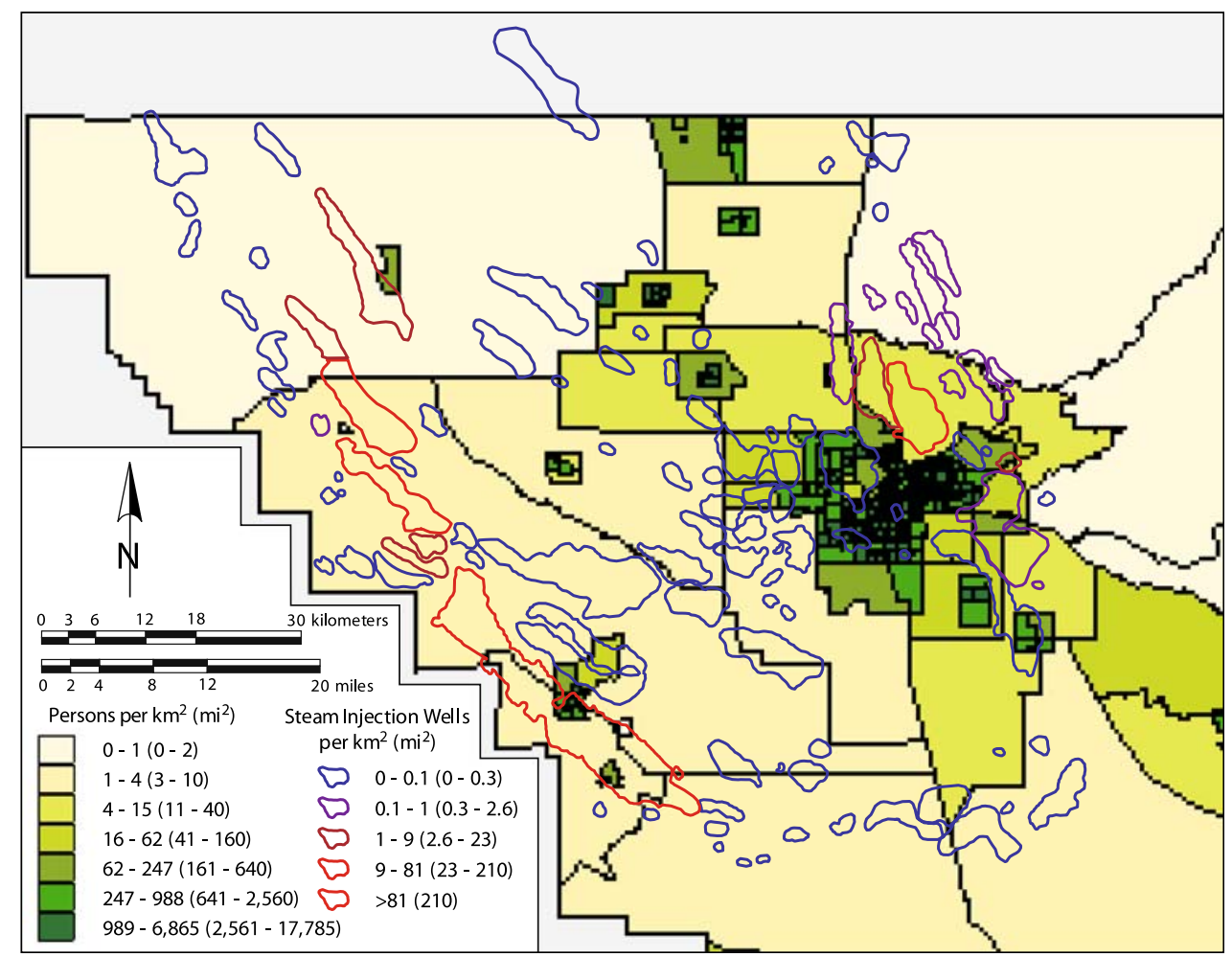

corrosion, or mis-installation, such as an improperly plugged well. Blowouts also occur because of surface activities marginally or completely unrelated to the well, such as construction accidents that damage a well head.

\section{Data and analysis}

Well blowout data used for this study

Four sources of blowout data were used for this study. DOGGR tracks surface well blowouts as a part of its mandate "to prevent, as far as possible, damage to life, health, property and natural resources" during "the drilling, operation, maintenance, and abandonment of wells (California PRC Section 3106)." In response to this mandate, DOGGR generates three sources of data concerning blowouts. DOGGR staff generates a paper report using a standard form for each blowout. These data are typically entered into an electronic database. DOGGR provided both copies of the paper records and the database for California Oil and Gas District 4 from 1991 to 2005. Additionally, DOGGR's "Annual report of the oil and gas supervisor" describes blowouts in District 4 for most of the study years (California Division of Oil, Gas and Geothermal Resources 1992-2006). In addition to data from DOGGR, staff at the Bakersfield Californian located all newspaper articles concerning blowouts during the study period. Newspaper staff can access both a digitally searchable archive covering the period from 1996 to the present, and a paper archive prior to this date.

Table 2 lists how many blowouts are reported, and reported uniquely (meaning only), by each of the four data sources. Thirty-two blowouts were (uniquely) reported by 
Fig. 5 Land use in western Kern County in 1998 (California Department of Water Resources undated)

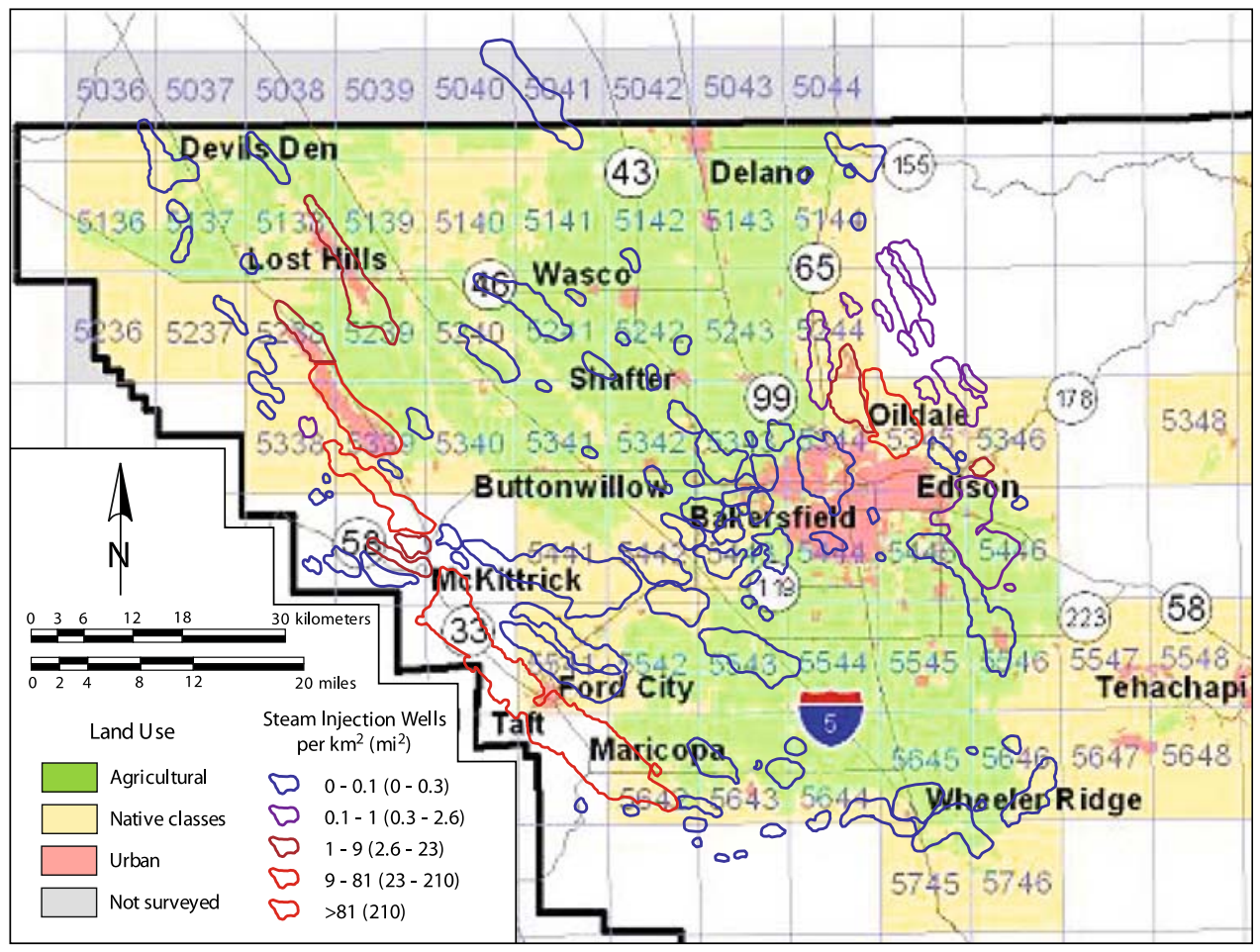

Table 2 Blowout count by data source

\begin{tabular}{lccc}
\hline & $\begin{array}{l}\text { Blowouts } \\
\text { listed }\end{array}$ & $\begin{array}{l}\text { Unique } \\
\text { blowouts }\end{array}$ & $\begin{array}{l}\text { Duplicated } \\
\text { blowouts }\end{array}$ \\
\hline $\begin{array}{l}\text { DOGGR paper } \\
\text { records }\end{array}$ & 66 & 4 & 62 \\
$\begin{array}{l}\text { DOGGR database } \\
\text { DOGGR } \\
\quad(1992-2006)\end{array}$ & 65 & 9 & 56 \\
$\begin{array}{c}\text { Bakersfield } \\
\text { Californian }\end{array}$ & 7 & 18 & 50 \\
Total & NA & 32 & 6 \\
\hline
\end{tabular}

only one source, 70 blowouts were reported by more than one source, and thus a total of 102 individual blowouts were identified. Thirty-two blowouts referred to simply as "steam blowouts" in the annual reports, with no further details, were assumed to correlate with steam blowouts in the other data sources.

The database and paper blowout records typically included the date, the activity taking place when the blowout occurred, and the cause of the blowout. These sources also provided data on the type, volume and duration of fluids escaping from the boring or well, and any injuries, equipment damage, or environmental damage that occurred. They also note if public impact, such as a road closure, resulted from the blowout. The newspaper articles tended to provide the most detail concerning public impacts, and also added detail concerning environmental damage.
Blowouts during the study period

The frequency of blowouts during the study period is shown in Fig. 6. A significant decline occurred during the study period. This decline is not explained by a decrease in activity in the district. Well drilling, as well as plugging and abandoning operations, generally increased in number during the study period, as did the number of active production and injection wells, while rework operations alone decreased. The quantity of fluid transferred through wells in the district did generally decrease, but only by approximately $15 \%$, so this alone could account for only a small portion of the decreasing number of blowouts annually. The average fluid transferred per well declined by approximately $30 \%$, but this could only account for a decline in blowouts from operating wells, and such blowouts are only about a third of all blowouts. A more likely explanation for the decline is increasing experience, improved technology, and/or changes in the safety culture in the oil and gas industry. For the purpose of this paper, the average blowout rates from the entire study period are calculated and evaluated. The blowout rate in the last 5 years of the study period is considerably lower than the average over the entire 15 -year study period.

The blowouts ranged in duration from $4-5 \mathrm{~s}$ to 6 months. Injury and environmental damage information was available for 76 and 75 blowouts, respectively. Environmental damage information was found in the "environmental damage" field as well as in the "cause" 
Fig. 6 Blowouts per year in California District 4 from 1991 to 2005

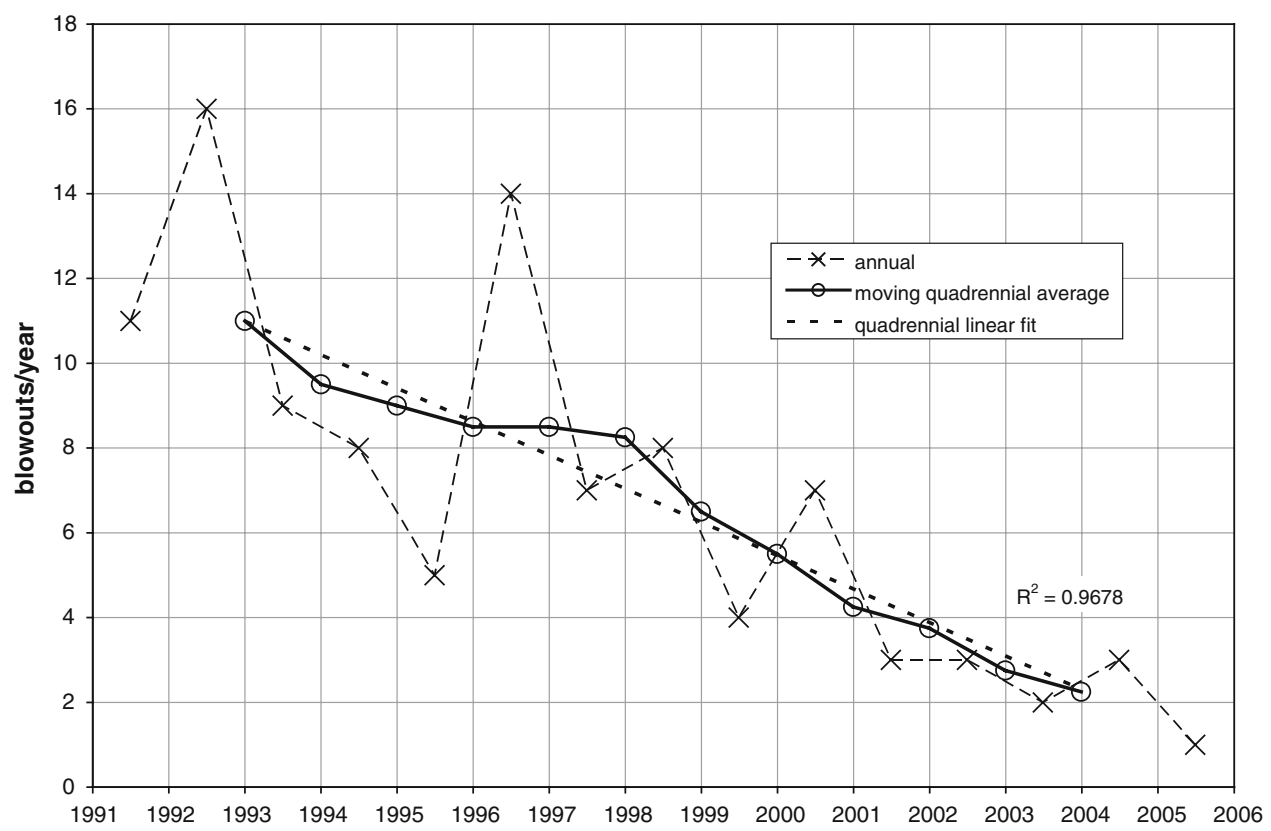

Table 3 Blowout duration, fluid type and fluid volume records and availability

\begin{tabular}{|c|c|c|c|c|c|}
\hline & Available & $\begin{array}{l}\text { Percentage } \\
\text { of all } \\
\text { blowouts }\end{array}$ & Median & $\begin{array}{l}\text { Fifth } \\
\text { percentile }\end{array}$ & $\begin{array}{l}\text { Ninety-fifth } \\
\text { percentile }\end{array}$ \\
\hline Duration & 70 & 69 & $6 \mathrm{~h}$ & $15 \mathrm{~min}$ & 3.5 days \\
\hline Fluid type & 83 & 81 & - & - & - \\
\hline $\begin{array}{l}\text { Fluid } \\
\text { volume }\end{array}$ & 42 & 41 & - & - & - \\
\hline
\end{tabular}

and "remarks" fields in the database and paper records provided by DOGGR.

No blowouts resulted in injuries or fatalities among the public. One blowout resulted in a worker fatality, and eight blowouts resulted in worker injuries during well drilling, reworking, servicing, and plugging and abandoning. Injuries included burns, abrasions, sprains, and bruises. The fatalities and injuries all occurred in the early to mid1990s, with one exception in 1998. This supports the conjecture that the decreasing blowout rate during the study period results from an increasing experience, technological improvements, and/or changes in safety culture in the oil and gas industry.

Of the 75 blowouts with environmental damage information, 21 resulted in environmental damage. This damage ranged from minor oil spills limited to a drilling pad to salting of tens of hectares (tens of acres) of agricultural land with brine. Public impact was not specifically tracked by DOGGR, but was noted in relation to some blowouts. The Bakersfield Californian articles also described the public impact associated with some blowouts. From this information, five blowouts were determined to have public impact, defined as affecting people's property, including structures and animals, or behavior. This impact ranged from temporary road closures, to evacuation of a school, to complete loss of a single-family, detached home under construction.

The number and percent of blowouts for which duration, fluid type, and fluid composition are available are shown in Table 3, along with some duration statistics.

The occurrence and amount of different fluid types and volumes during blowouts are given in Table 4. Steam volumes were not available. Gas volumes are in standard cubic feet, as opposed to estimated in-reservoir volumes elsewhere in this study.

The blowouts were coded for four parameters to allow analysis of rates during different phases of oil-field development and operation. The parameters are activity, reservoir conditions, well type, and blowout location at the time of the blowout. The possible codes for each of these parameters are shown in Table 5. All four parameters were coded for 82 of the blowouts, which is $80 \%$ of the data set. The remaining 20 blowouts were partially coded. Of these, 18 were in thermal-recovery areas. The remaining two could not be coded for recovery, but were coded for activity. The proportions of coded blowout types were used to normalize the total set of 102 blowouts. In other words, these proportions were used to assign the 20 partially coded blowouts (or portions thereof) to specific blowout categories.

The activity and blowout location were coded based upon the blowout data provided by DOGGR and the Bakersfield Californian. The well type was coded based upon 
Table 4 Blowout fluid types and volumes

\begin{tabular}{|c|c|c|c|c|c|c|c|}
\hline & \multirow[t]{2}{*}{ Blowouts } & \multirow{2}{*}{$\begin{array}{l}\text { Percentage of all } \\
\text { blowouts with fluid } \\
\text { type available }\end{array}$} & \multirow{2}{*}{$\begin{array}{l}\text { Fluid volume } \\
\text { emitted available }\end{array}$} & \multirow{2}{*}{$\begin{array}{l}\text { Percentage of blowouts } \\
\text { emitting this fluid } \\
\text { with volume available }\end{array}$} & \multicolumn{3}{|l|}{ Volume } \\
\hline & & & & & Median & $\begin{array}{l}\text { Fifth } \\
\text { percentile }\end{array}$ & $\begin{array}{l}\text { Ninety-fifth } \\
\text { percentile }\end{array}$ \\
\hline Steam & 55 & 66 & 0 & 0 & NA & NA & NA \\
\hline Oil $\left(\mathrm{m}^{3}, \mathrm{bbl}\right)$ & 39 & 47 & 26 & 68 & $2.4(15)$ & $0.05(0.33)$ & $80(500)$ \\
\hline Water $\left(\mathrm{m}^{3}, \mathrm{bbl}\right)$ & 34 & 41 & 20 & 59 & $14(88)$ & $0.3(2)$ & $37,000(230,000)$ \\
\hline Gas $\left(\mathrm{Mm}^{3}, \mathrm{MMcf}\right)$ & 22 & 27 & 9 & 41 & $62(2.2)$ & $0.006(0.0002)$ & $94,000(3,300)$ \\
\hline Earth $\left(\mathrm{m}^{3}, \mathrm{ft}^{3}\right)$ & 16 & 19 & 6 & 38 & $2.3(81)$ & $0.035(1.3)$ & $740(26,000)$ \\
\hline
\end{tabular}

Table 5 Blowout parameters and parameter codes

\begin{tabular}{|c|c|c|}
\hline Parameter & $\begin{array}{l}\text { Parameter value } \\
\text { (code) }\end{array}$ & Note \\
\hline \multirow{6}{*}{$\begin{array}{l}\text { Activity at time of } \\
\text { blowout }\end{array}$} & (d)rilling & - \\
\hline & (r)eworking & - \\
\hline & (s)ervicing & - \\
\hline & (a)bandoning & - \\
\hline & (n)one & Well in operation, shut in, or abandoned \\
\hline & (o)ther & $\begin{array}{l}\text { Blowout due to non-well related event, such as a car } \\
\text { crash }\end{array}$ \\
\hline \multirow[t]{2}{*}{ Recovery type } & (t)hermal & Involved in thermally enhanced recovery \\
\hline & (o)ther & Not involved in thermally enhanced recovery \\
\hline \multirow[t]{5}{*}{ Well type } & (p)roduction & Includes exploratory wells \\
\hline & (i)njection & Cyclic-steam wells coded as "ip" \\
\hline & (s)hut in & - \\
\hline & (a)bandoned & - \\
\hline & (o)bservation & - \\
\hline \multirow[t]{2}{*}{ Blowout location } & (w)ell & $\begin{array}{l}\text { Blowout from wellhead, associated piping, casing or } \\
\text { annulus }\end{array}$ \\
\hline & (g)round surface & $\begin{array}{l}\text { Blowout from ground surface at any distance away } \\
\text { from well }\end{array}$ \\
\hline
\end{tabular}

the well type and status listed in DOGGR's production and injection data files (California Division of Oil, Gas and Geothermal Resources 2007) using the API well number as available, along with the blowout record. The reservoir condition was assumed "thermal" for steam-injection wells, and was assigned as "thermal" for other wells with a mention of steam in the blowout record. (The blowout data and coding are presented in Appendix 1 of "Supplementary material" and additional notes on the coding are included in Appendix 2 of "Supplementary material".)

Both steam flood and cyclic steaming took place in District 4 during the study period. Cyclic-steam wells are coded "ip" for well type because they are both injectors and producers. Recovery type "(o)ther" in District 4 includes fields on primary production, production with gas pressure maintenance, and secondary production using water and air ("fire") floods.
Blowout rates and consequences during well drilling, rework, and plugging and abandonment

During well drilling, reworking, and plugging and abandoning (P\&A), a total of 32 coded blowouts occurred in District 4 during the study period. Over 78,000 of these wellwork operations were performed during this same time period (California Division of Oil, Gas and Geothermal Resources 1992-2006). Blowout rates were calculated by dividing the number of blowouts during a certain type of operation by the number of these operations during the study period. For instance, the drilling blowout rate is the number of blowouts during drilling, divided by the total number of borings drilled during the study period. More detail concerning these calculations is included in Appendix 2. The calculated blowout rates during drilling, reworking, and plugging and abandoning are provided in Fig. 7 and Table 6. 
Fig. 7 Blowout rates and consequences during well drilling, reworking, and plugging and abandoning in District 4 from 1991 to 2005. Areas of overlapping cross hatch and stipple indicate the rate of blowouts causing both injury and environmental damage

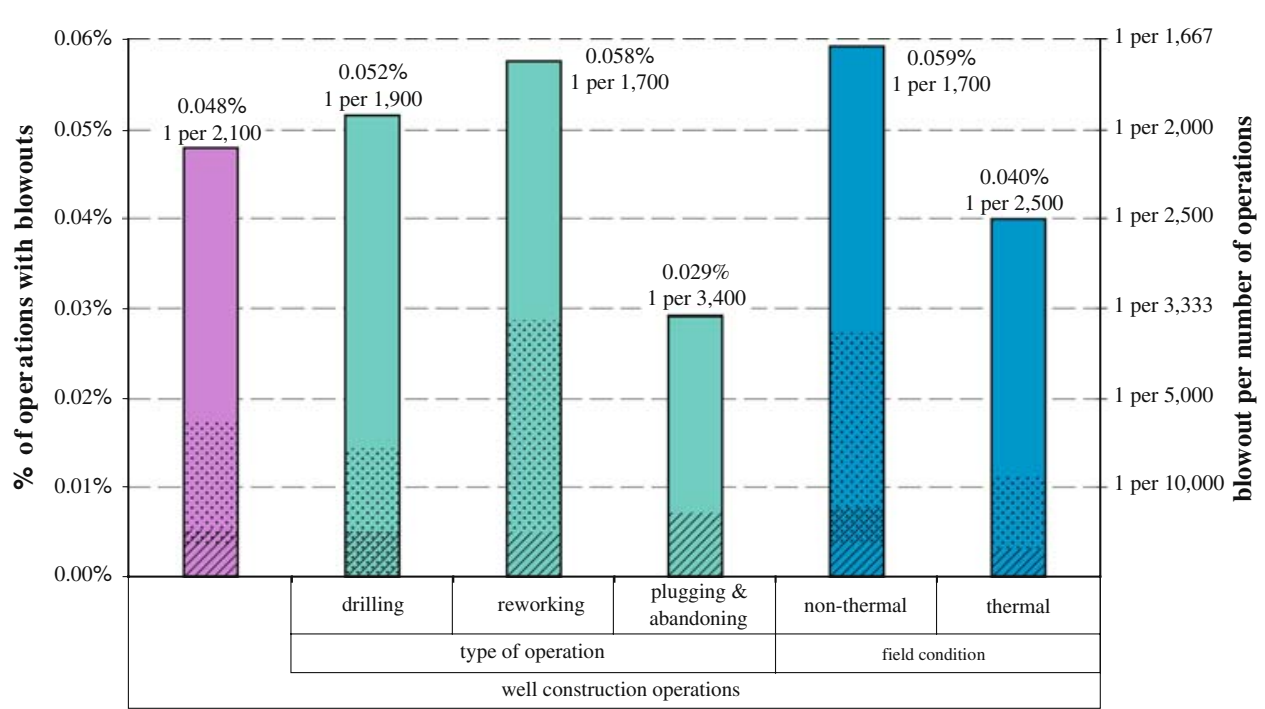

blowouts causing injury blowouts causing environmental damage

Table 6 Well blowout rates in District 4 during well construction in the period 1991-2005

\begin{tabular}{|c|c|c|c|c|c|c|}
\hline & \multirow[t]{2}{*}{ All } & \multicolumn{3}{|c|}{ By type of construction operation } & \multicolumn{2}{|l|}{ By field type } \\
\hline & & Drilling & Reworking & $\begin{array}{l}\text { Plugging and } \\
\text { abandoning }\end{array}$ & Non-thermal & Thermal \\
\hline Coded blowouts & 32 & 13 & 14 & 5 & 19 & 12 \\
\hline $\begin{array}{l}\text { Normalized \# of } \\
\text { blowouts }\end{array}$ & 37.5 & 15.2 & 16.4 & 5.9 & 19.6 & 17.9 \\
\hline $\begin{array}{l}\text { Number of operations } \\
\text { (1991-2005 total) }\end{array}$ & 78,100 & 29,516 & 28,500 & 20,097 & 33,000 & 45,000 \\
\hline $\begin{array}{l}\text { Construction operation } \\
\text { description }\end{array}$ & $\begin{array}{l}\text { Wells drilled, } \\
\text { reworked } \\
\text { (estimated) } \\
\text { and P\&A }\end{array}$ & Wells drilled & $\begin{array}{l}95 \% \text { of the well } \\
\text { reworking } \\
\text { permits }\end{array}$ & $\begin{array}{l}\text { Wells plugged } \\
\text { and abandoned }\end{array}$ & $\begin{array}{l}\text { Estimated wells } \\
\text { drilled, reworked } \\
\text { and P\&A in non- } \\
\text { thermal areas }\end{array}$ & $\begin{array}{l}\text { Estimated wells } \\
\text { drilled, reworked } \\
\text { and P\&A in } \\
\text { thermal areas }\end{array}$ \\
\hline $\begin{array}{l}\text { Operations with } \\
\text { blowouts }(\%)\end{array}$ & 0.048 & 0.052 & 0.058 & 0.029 & 0.059 & 0.040 \\
\hline $\begin{array}{l}\text { Blowout per number } \\
\text { of operations }\end{array}$ & 1 per 2,100 & 1 per 1,900 & 1 per 1,700 & 1 per 3,400 & 1 per 1,700 & 1 per 2,500 \\
\hline Portion causing injury & $10 \%(3 / 27)$ & $10 \%(1 / 11)$ & $10 \%(1 / 12)$ & $25 \%(1 / 4)$ & $15 \%(2 / 15)$ & $10 \%(1 / 11)$ \\
\hline $\begin{array}{l}\text { Portion causing } \\
\text { environmental } \\
\text { damage }\end{array}$ & $30 \%(8 / 27)$ & $25 \%(3 / 11)$ & $40 \%(5 / 12)$ & $0 \%(0 / 4)$ & $40 \%(6 / 15)$ & $20 \%(2 / 11)$ \\
\hline
\end{tabular}

Three of the blowouts during well work had public impact, one during each type of well work. All three of these blowouts were in non-thermal fields. This impact included an electrical outage at a farm, closure of a road, and evacuation of 24 people from 10 homes. As only the occurrence, rather than the lack of occurrence, of public impact was available, the portion of blowouts resulting in public impact is not given in the tables in this paper. However, the inclusion of newspaper data suggests there was not likely significantly more or greater public impact than included in this paper's data set.

The worker injury and environmental damage consequences were available for 27 of the 32 blowouts coded for drilling, reworking, and plugging and abandoning. The portion of blowouts with each of these consequence types during these activities is shown in Fig. 7 and Table 6.

The worker injuries varied in severity. A worker fatality occurred, and two workers were burned, during preparation for plugging and abandoning a single well in a non-thermal field. A worker suffered a minor concussion resulting from a fall during a drilling blowout in a non-thermal field. A worker's foot was burned during preparation for reworking in a thermal field.

One blowout during reworking in a non-thermal field in Rosedale misted seven single-family homes and associated 
grounds, as well as equipment and domestic animals (including horses and dogs). One of the misted homes was under construction and had been framed and sheathed. The structure had to be torn down as a result of the oil misting and framing restarted, resulting in several lawsuits. Another blowout during plugging and abandoning in a nonthermal field resulted in a highway closure.

Environmental damage from the blowouts ranged from "minor" oil misting to oil misting with $18 \mathrm{~m}^{3}$ (150 bbl) of oil over approximately 30 ha (70 acres). Damage during drilling and reworking was similar, but damage from nonthermal blowouts tended to cover 10 ha ( 25 acres) or more, while the damage area from thermal blowouts was smaller, although the data were too few to show this statistically.

The median blowout duration was $6 \mathrm{~h}$, with drilling blowouts having durations of $8 \mathrm{~h}$, reworking blowouts $6 \mathrm{~h}$, and plugging and abandoning blowouts $12 \mathrm{~h}$. The median non-thermal and thermal field blowout durations were 18 and $6 \mathrm{~h}$, respectively. These differences were not significant at the 5\% level, however. The shortest and longest blowouts were $20 \mathrm{~min}$ and 6 months, respectively, with the latter during drilling of an exploratory gas well.

\section{Blowout rates and consequences during well operations}

During well production and injection operations, a total of 48 coded blowouts occurred from operating wells in District 4 during the study period. Two approaches were used to assess these blowout rates. In the first approach, the number of blowouts from a certain well type was divided by the annual average number of wells of this type, and by the study period duration in years. For instance, the production blowout rate is blowouts during production, divided by the annual average number of production wells, divided by 15 years. This yields the blowout rate in blowouts per well per year (sometimes referred to as blowouts per well year). The number of wells used for this analysis was obtained from California Division of Oil, Gas and Geothermal Resources (1992-2006). The assignment of wells to thermal versus non-thermal fields, as well as steam flood versus cyclic steaming, is discussed in Appendix 2.

In the second approach, rates were calculated based on the fluid volume transferred. For instance, the blowout rate for steam-injection wells was blowouts divided by the volume of steam injected during the study period. The fluid volume production and injection data used for this analysis were obtained from California Division of Oil, Gas and Geothermal Resources (1992-2006). Pressure data used to determine steam/water densities, necessary for calculating steam-injection volumes, were obtained from the DOGGR's production and injection data files (California Division of Oil, Gas and Geothermal Resources 2007).
During the study period, approximately 490 million $\mathrm{m}^{3}$ (3.1 billion bbl) of oil, 67 billion standard $\mathrm{m}^{3}$ (2.4 trillion standard $\mathrm{ft}^{3}$ ) of gas and 2.9 billion $\mathrm{m}^{3}$ (18 billion bbl) of water were produced. Other approximate injection volumes were 19 billion $\mathrm{m}^{3}$ ( 670 billion standard $\mathrm{ft}^{3}$ ) of gas for pressure maintenance, 1.1 billion $\mathrm{m}^{3}$ (7.0 billion bbl) of steam (liquid equivalent), 430 million $\mathrm{m}^{3}$ ( 2.7 billion bbl) of water for flooding, and 760 million $\mathrm{m}^{3}$ (4.8 billion bbl) of disposal water. The conversion of the liquid equivalent steam volume to the actual steam/water volume passing through the wells is discussed below. The conversion of the standard gas volume to actual well flow volume, and the distribution of the fluid volumes to thermal versus nonthermal fields and steam flood versus cyclic steaming, are discussed in Appendix 2.

For the rate of blowouts per-fluid volume in thermal fields, the liquid equivalent of steam injected as reported in the California Division of Oil, Gas and Geothermal Resources (1992-2006) was converted to the approximate steam/water volume. The steam fraction on a mass basis at the injection well head was assumed to be 0.70 , with the remainder liquid water (Mike Stettner and Alfredo Urdaneta, personal communication). The average steaminjection pressure at the well head was taken as $3 \mathrm{MPa}$ (440 psi) based upon California Division of Oil, Gas and Geothermal Resources (2007). The vapor-to-liquid volume ratio for equivalent masses at this pressure is approximately 67 . The steam volume resulting from these values (the "at well head" volume) was used in all the steaminjection well blowout rates.

The mass fraction of water produced as steam was assumed to be 0.05 of the total water produced, which is in agreement with production company estimates (Alfredo Urdaneta, personal communication). The average thermalproduction-well pressure at the well head was taken as $1 \mathrm{MPa}$ (145 psi) absolute based upon California Division of Oil, Gas and Geothermal Resources (2007). At this pressure, the vapor-to-liquid volume ratio for equivalent water masses is approximately 200.

Application of the values above gives steam/water volumes of 52 billion $\mathrm{m}^{3}$ (330 billion bbl) injected at the well head, and 21 billion $\mathrm{m}^{3}$ (130 billion bbl) produced at the well head in thermal-recovery areas. These volumes are approximately 69 and 28 times greater than the volume of the other fluids (primarily oil and disposal water) transferred between the surface and subsurface in thermal fields, respectively.

The blowout rates during well servicing, and production and injection operations, are shown in Figs. 8 and 9 and Tables 7 and 8 . The well servicing blowout rate uses the annual average well count or total fluid volume, rather than service operations. This is because DOGGR does not track the number of service operations. Therefore, the servicing 
Fig. 8 Well blowouts per well per year for operating wells in District 4 from 1991 to 2005
Fig. 9 Well blowouts per fluidvolume transferred during production and injection in District 4 from 1991 to 2005
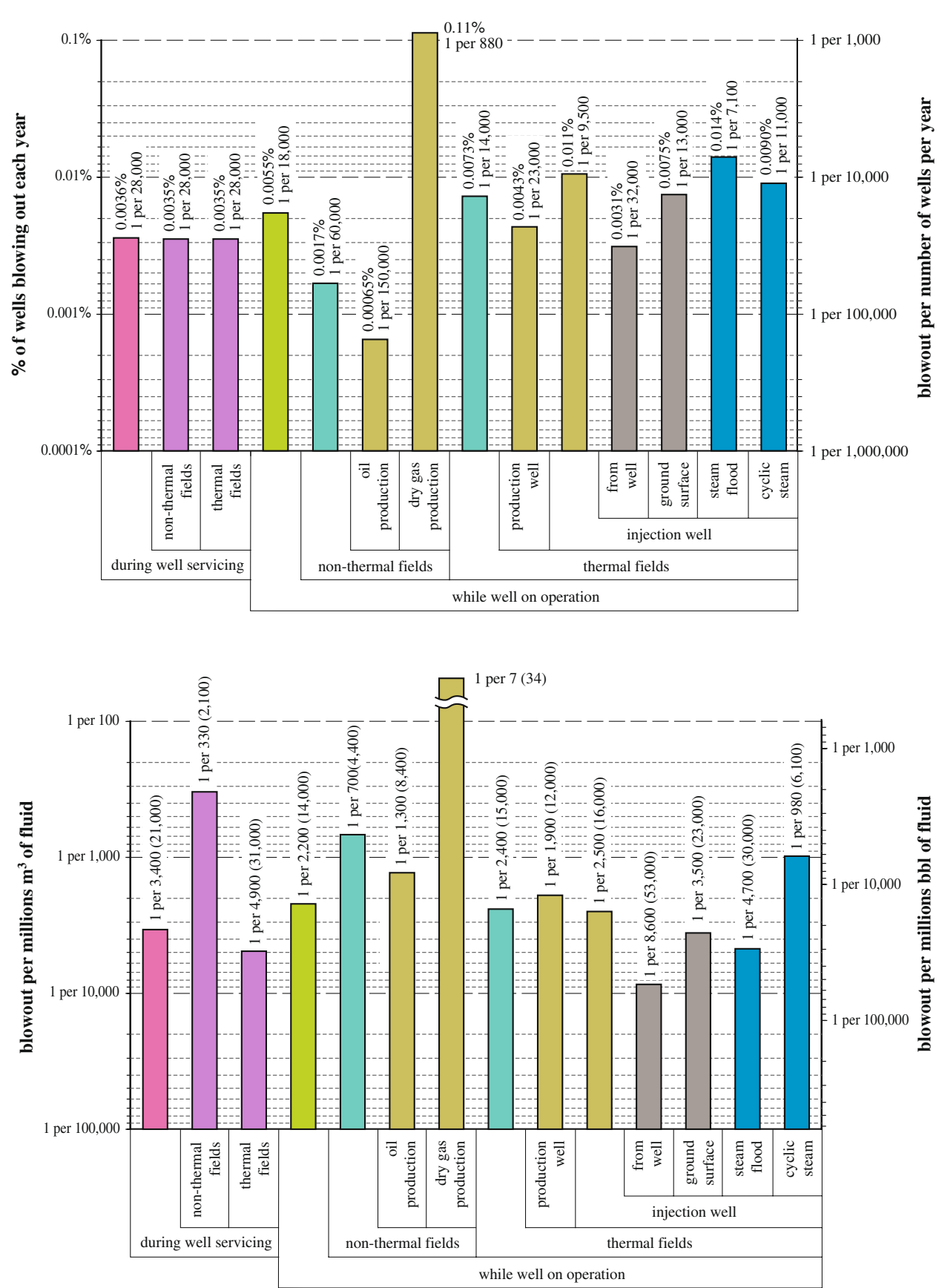

blowout rate is in different units and should not be compared with the drilling, reworking, and plugging and abandoning rates. The blowout rate during well servicing combines the probability that a well will be serviced with the probability that it will experience a blowout during servicing. For instance, if $10 \%$ of the wells were serviced in a year, then the blowout rate per well servicing operation would be ten times that of the per well per year rate given in Figs. 8 and 9 and Table 7.

Almost all operational wells are serviced each year in thermal fields, while a considerably lower fraction is serviced each year in non-thermal fields (Alfredo Urdaneta, personal communication). Therefore even though the blowout rate during well servicing is almost the same in thermal versus non-thermal fields on a per well per year basis (as shown in Fig. 8 and Table 7), the rate on a perservicing operation basis is actually considerably higher in non-thermal as compared to thermal fields.

About a quarter of the blowouts during well servicing resulted in worker injury, and about a quarter resulted in environmental damage, as shown in Table 7. The injuries consisted of abrasions, bruises, sprains, and burns, with no noteworthy difference between non-thermal and thermal fields. The environmental damage consisted of various 


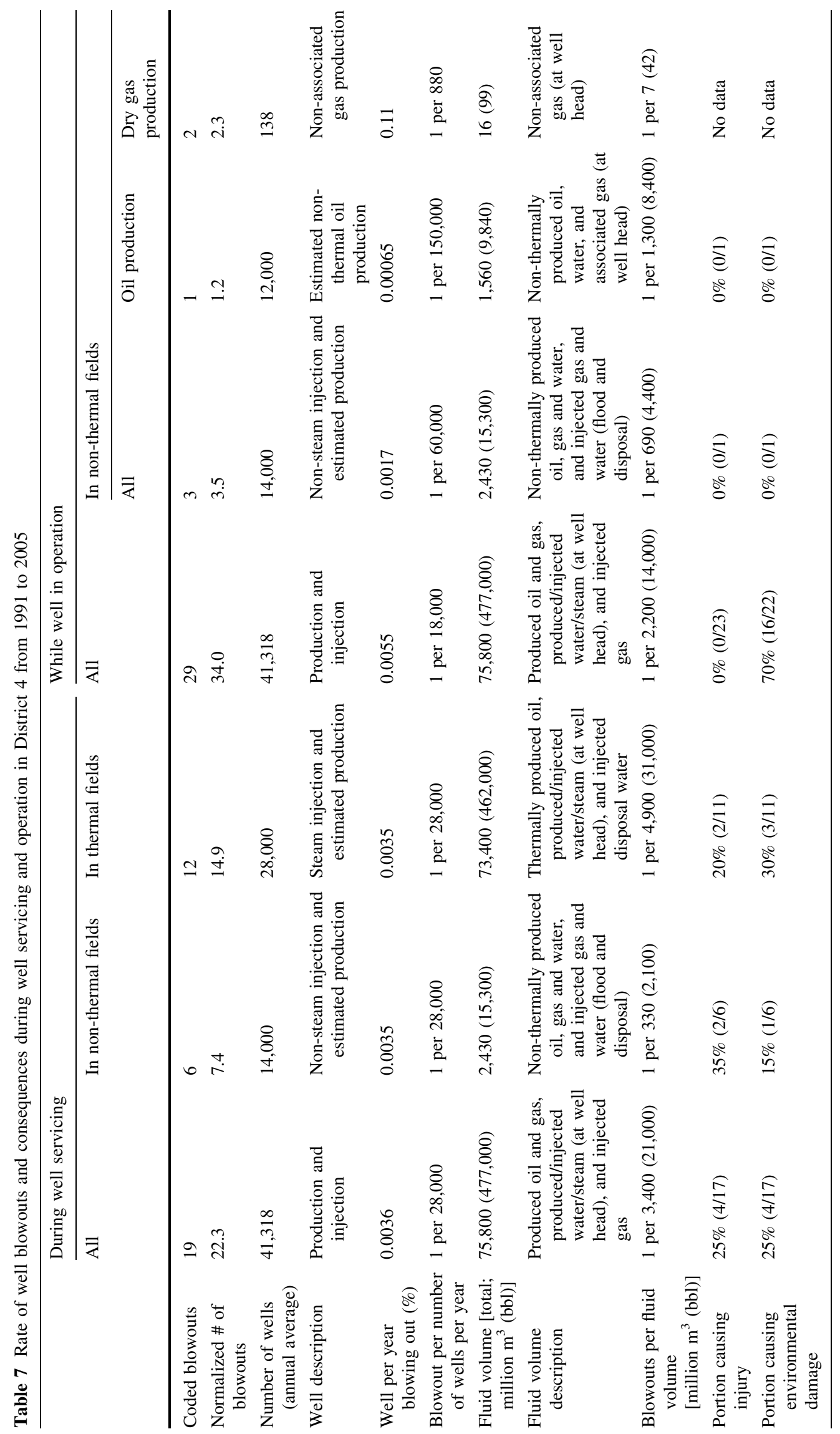


Fig. 10 Percentage of blowouts causing worker injury and environmental damage.

Overlapping patterns indicate blowouts resulting in both types of consequences

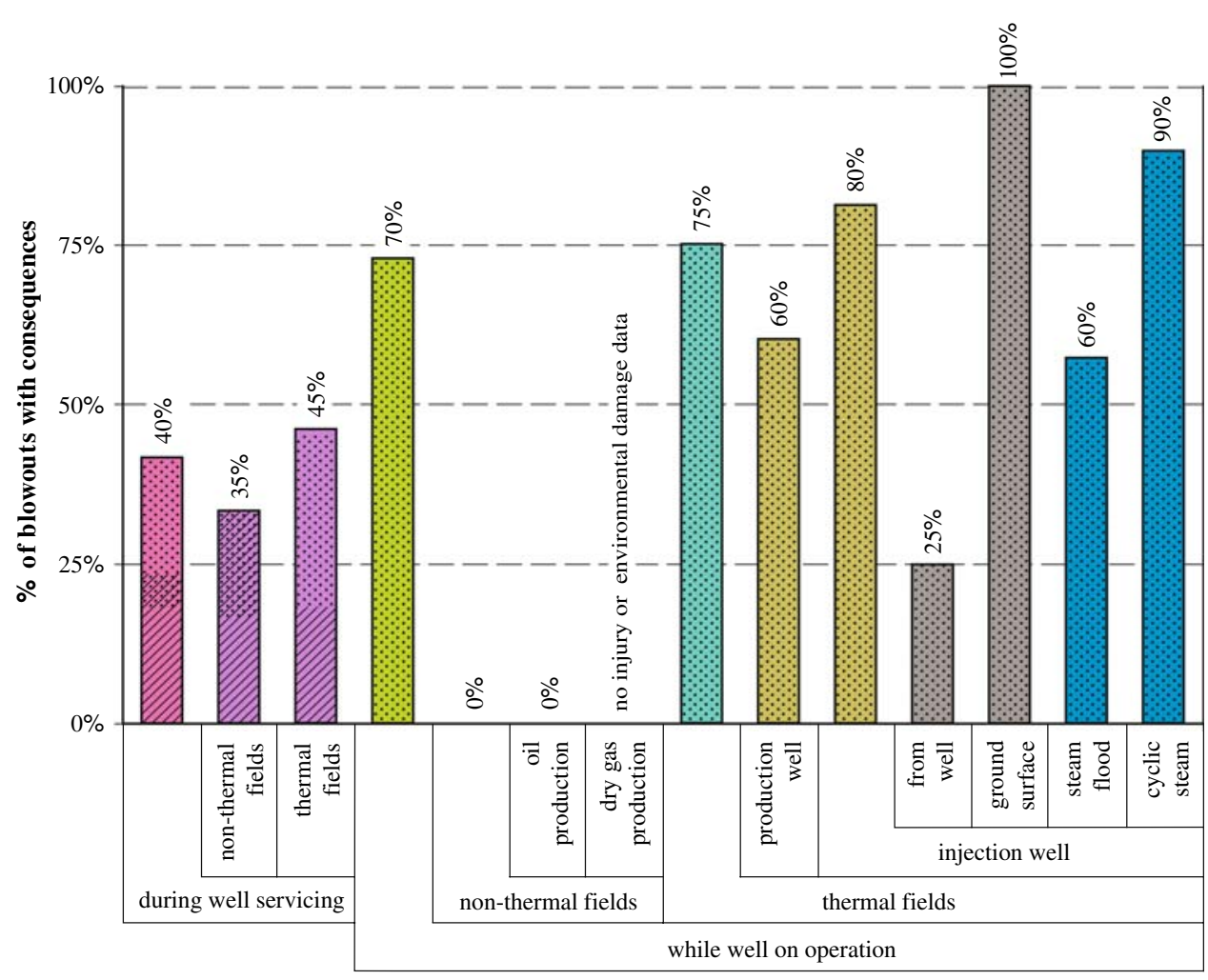

concentrations of oil covering a fifth of a hectare (a half acre) to oil covering 16 ha (41 acres), again with no notable difference between non-thermal and thermal fields. There was no public impact. The median duration of blowouts during servicing was $8 \mathrm{~h}$. The median duration in thermal and non-thermal fields was 1 and $10 \mathrm{~h}$, respectively.

Blowouts from wells in operation caused no injuries or fatalities. The single blowout from a well in operation in a non-thermal field did not cause any environmental damage, either. The only public impact was evacuation of a school and closure of a highway during a thermal production well blowout. Three-fifths of the thermal-production-well blowouts caused environmental damage, as shown in Fig. 10 and Table 8. This damage consisted of a couple of hectares (several acres) of lightly oil-misted ground to approximately 15 ha (40 acres) of oil-misted ground. The median thermal production blowout duration was $6 \mathrm{~h}$.

All blowouts from the ground surface, rather than at the well, were associated with steam-injection wells. Therefore the ground-surface blowout rate is based only on the number of steam injectors and the injected steam volume. No impact was noted in the "environmental damage" field in the DOGGR database for these blowouts. However, the "cause" and "remarks" fields indicate such blowouts occurred from 6 to $200 \mathrm{~m}$ ( $20 \mathrm{ft}$ to 200 yards) from the nearest well and caused displacement of earth from the blowout fracture. The amount of earth displaced ranged from a $30 \mathrm{~cm}(1 \mathrm{ft})$ tall cone to a mound $2 \mathrm{~m}(6 \mathrm{ft})$ high by $3 \mathrm{~m}(10 \mathrm{ft})$ in diameter. On this basis, all ground-surface blowouts are conservatively taken in this report as causing environmental damage, owing to the potential disruption of the surrounding property. About a fourth of steam-injection-well blowouts from the ground surface also involved flows or sprays of oil, but the spread of this oil appears to have been small.

Note that some of the well blowouts listed in the data sources as coming from the ground surface rather than at the well may not have been caused by well-casing failures in the subsurface, but rather by leakage along geological pathways (Mark Gamache, personal communication). These can be difficult to discriminate, and no attempt to do so has been made in this paper. All ground-surface blowouts listed in the data sources used were treated as well blowouts; consequently, the actual steam-injection-well blowout rates may be lower than calculated.

No blowouts occurred from injection wells other than steam wells. These wells include, in decreasing numbers, wells for water flood and disposal, pressure maintenance (natural gas injection) and air injection (fire flood). Taking the cumulative number of well years for these injectors as a group, they blow out at a rate equal to or less than approximately 1 per 29,000 wells per year. This rate is approximately a third of that for steam injectors. 


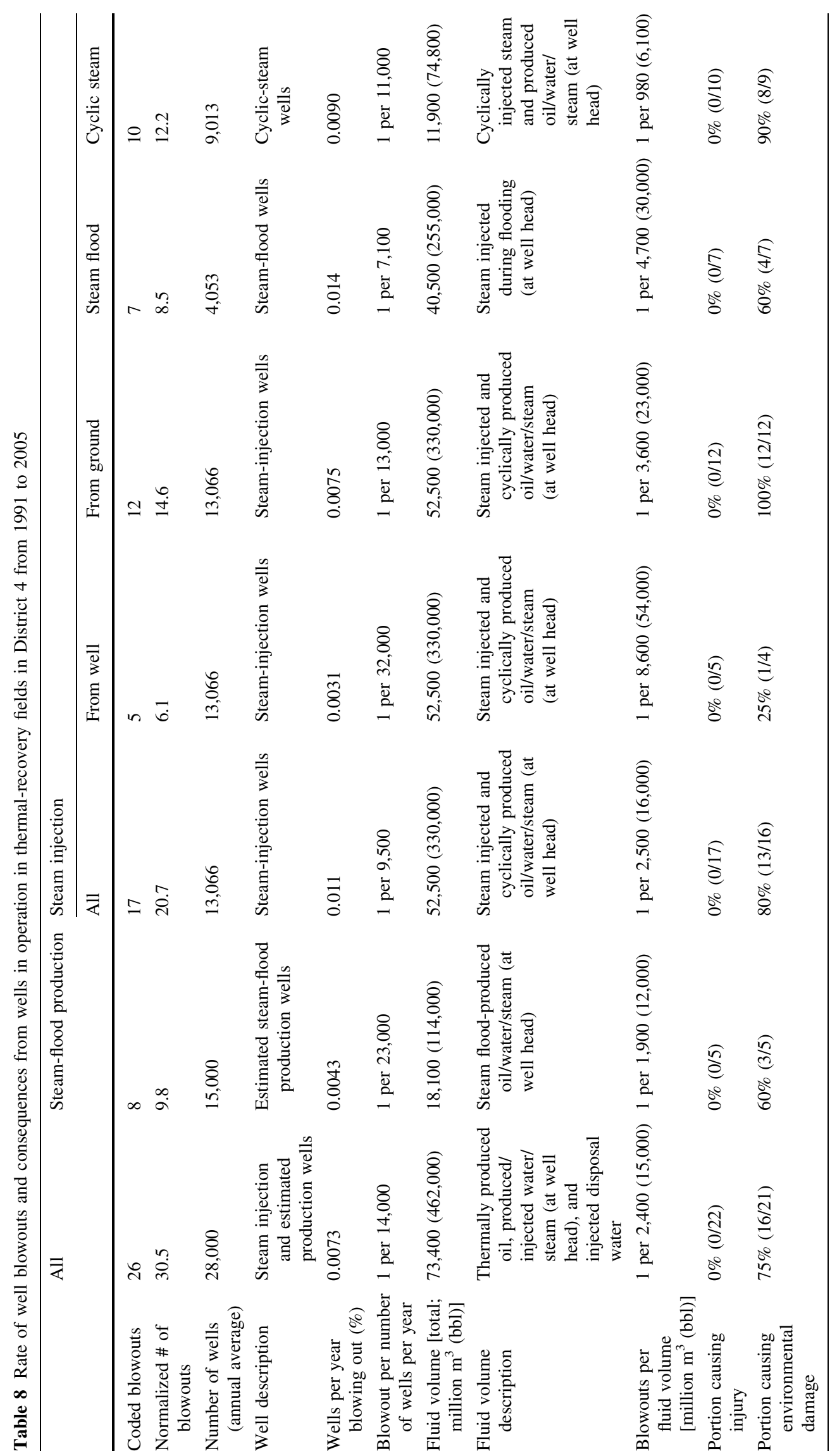


Table 9 Rate of well blowouts and consequences from non-operational wells (shut-in/idle vs. abandoned) in District 4 from 1991 to 2005

\begin{tabular}{|c|c|c|c|c|c|c|c|}
\hline & \multirow[t]{2}{*}{ All } & \multicolumn{3}{|l|}{ Shut-in/idle } & \multicolumn{3}{|l|}{ Abandoned } \\
\hline & & All & $\begin{array}{l}\text { In non-thermal } \\
\text { fields }\end{array}$ & $\begin{array}{l}\text { In thermal } \\
\text { fields }\end{array}$ & & $\begin{array}{l}\text { In non-thermal } \\
\text { fields }\end{array}$ & $\begin{array}{l}\text { In thermal } \\
\text { fields }\end{array}$ \\
\hline Coded blowouts & 5 & 2 & 1 & 1 & 3 & 0 & 3 \\
\hline $\begin{array}{l}\text { Normalized \# of } \\
\text { blowouts }\end{array}$ & 5.9 & 2.3 & 1.2 & 1.2 & 3.5 & $<1$ & 3.5 \\
\hline $\begin{array}{l}\text { Number of wells } \\
\text { (annual average) }\end{array}$ & 53,742 & 18,660 & 8,400 & 10,000 & 35,081 & 12,000 & 23,000 \\
\hline Well description & $\begin{array}{l}\text { Idle/shut-in } \\
\text { and P\&A } \\
\text { wells }\end{array}$ & $\begin{array}{l}\text { Idle/shut-in } \\
\text { wells }\end{array}$ & $\begin{array}{l}\text { Estimated shut-in/ } \\
\text { idle wells in non- } \\
\text { thermal areas }\end{array}$ & $\begin{array}{l}\text { Estimated shut-in/ } \\
\text { idle wells in } \\
\text { thermal areas }\end{array}$ & P\&A wells & $\begin{array}{l}\text { Estimated P\&A } \\
\text { wells in non- } \\
\text { thermal areas }\end{array}$ & $\begin{array}{l}\text { Estimated } \\
\text { P\&A } \\
\text { wells in } \\
\text { thermal } \\
\text { areas }\end{array}$ \\
\hline $\begin{array}{l}\text { Wells per year } \\
\text { blowing out }(\%)\end{array}$ & 0.00073 & 0.00084 & 0.00093 & 0.00078 & 0.00067 & $<0.00056$ & 0.0010 \\
\hline $\begin{array}{l}\text { Blowout per number } \\
\text { of wells per year }\end{array}$ & 1 per 140,000 & 1 per 120,000 & 1 per 110,000 & 1 per 130,000 & 1 per 150,000 & $<1$ per 180,000 & 1 per 98,000 \\
\hline Portion causing injury & $0 \%(0 / 4)$ & $0 \%(0 / 1)$ & No data & $0 \%(0 / 1)$ & $0 \%(0 / 3)$ & No data & $0 \%(0 / 3)$ \\
\hline $\begin{array}{l}\text { Portion causing } \\
\text { environmental } \\
\text { damage }\end{array}$ & $25 \%(1 / 4)$ & $0 \%(0 / 1)$ & No data & $0 \%(0 / 1)$ & $35 \%(1 / 3)$ & No data & $35 \%(1 / 3)$ \\
\hline
\end{tabular}

Table 10 Rate of well blowouts and consequences from non-operational wells in non-thermal vs. thermal fields and during other events in District 4 from 1991 to 2005

\begin{tabular}{|c|c|c|c|c|}
\hline & \multicolumn{3}{|l|}{ Not operational } & \multirow[t]{2}{*}{ During other events } \\
\hline & All & In non-thermal fields & In thermal fields & \\
\hline Coded blowouts & 5 & 2 & 3 & 2 \\
\hline Normalized \# of blowouts & 5.9 & 2.3 & 3.5 & 2.3 \\
\hline Number of wells (annual average) & 53,742 & 21,000 & 33,000 & 59,978 \\
\hline Well description & $\begin{array}{l}\text { Idle/shut-in and } \\
\text { P\&A wells }\end{array}$ & $\begin{array}{c}\text { Estimated shut-in/idle } \\
\text { and P\&A wells in } \\
\text { non-thermal areas }\end{array}$ & $\begin{array}{l}\text { Estimated shut-in/idle } \\
\text { and P\&A wells in } \\
\text { thermal areas }\end{array}$ & $\begin{array}{l}\text { Production, injection } \\
\text { and shut-in wells }\end{array}$ \\
\hline Wells per year blowing out $(\%)$ & 0.00073 & 0.00037 & 0.00095 & 0.00026 \\
\hline Blowout per number of wells per year & 1 per 140,000 & 1 per 270,000 & 1 per 110,000 & 1 per 380,000 \\
\hline Portion causing injury & $0 \%(0 / 4)$ & No data & $0 \%(0 / 4)$ & $0 \%(0 / 2)$ \\
\hline Portion causing environmental damage & $25 \%(1 / 4)$ & No data & $25 \%(1 / 4)$ & $0 \%(0 / 2)$ \\
\hline
\end{tabular}

Approximately 1.2 billion $\mathrm{m}^{3}$ (7.8 billion bbl) of fluid were injected through these other wells. This is more than the average fluid volume per cyclic-steam-injector blowout, but less than the average fluid per steam-flood-injector blowout. Therefore, the data set studied provides some constraint on the relationship between non-steam and steam-injector blowout rates per-fluid volume.

Blowout rates and consequences for shut-in/idle and abandoned wells, and during "other events"

Five blowouts occurred from shut-in/idle and abandoned wells in District 4 during the study period. Table 9 shows the blowout rate for each of these well types, as well as the rates in non-thermal versus thermal fields for each well type. Table 10 shows the rates in non-thermal and thermal fields for the two well types combined. The rates from Tables 9 and 10 are shown in Fig. 11.

The three blowouts from abandoned wells all involved steam. Two of these wells had approved plugs. The plugging status of the third well at the time of the blowout is unknown, but it appears to have been poorly located and likely not properly plugged, since the blowout material included "wood debris." The thermal blowouts from these abandoned wells resulted in no injuries. One resulted in environmental damage consisting of a crater at the well and 
Fig. 11 Well blowouts per well per year for non-operating wells in District 4 from 1991 to 2005

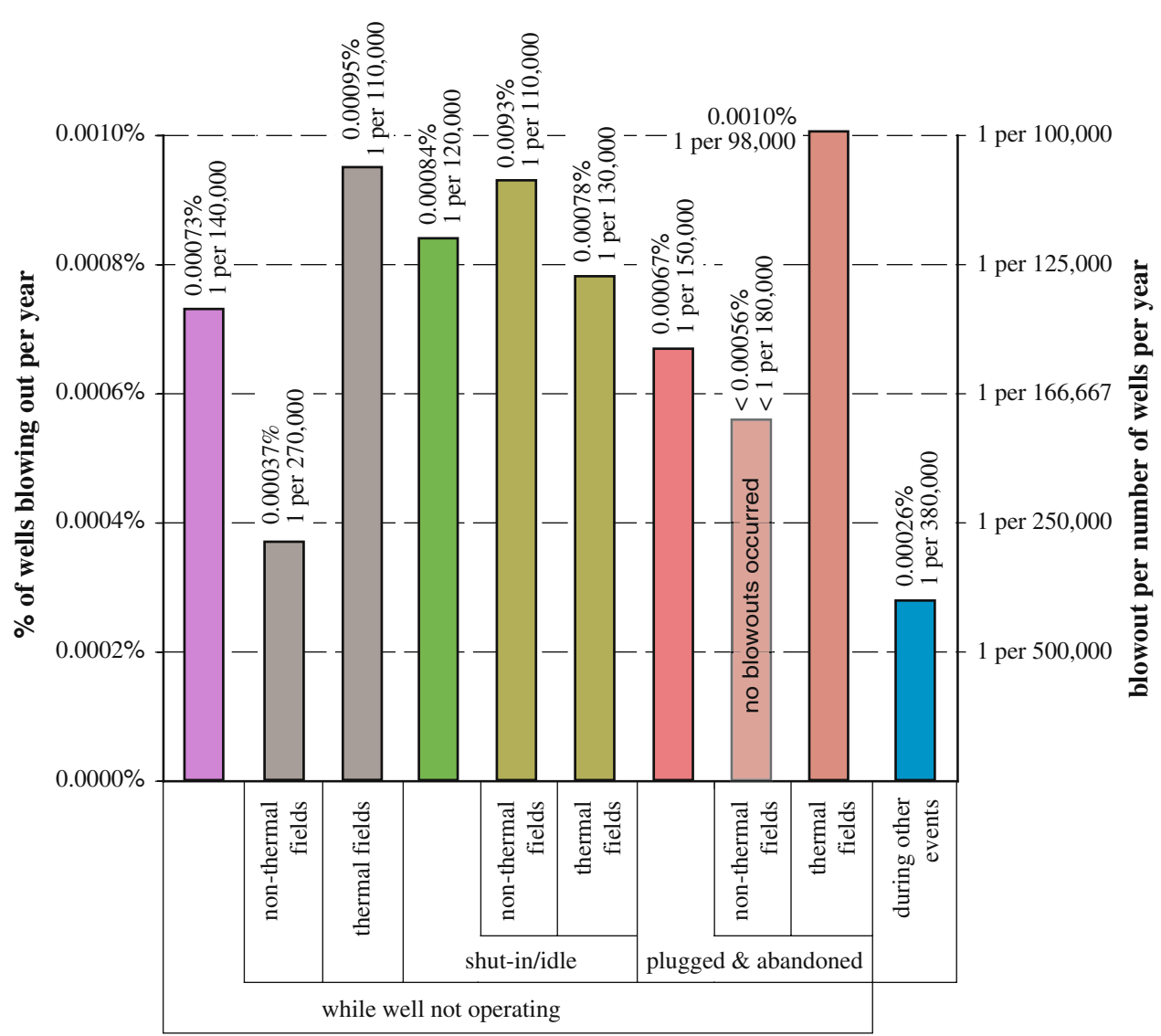

displaced earth piled up to $5 \mathrm{~m}(15 \mathrm{ft})$ high and covering an area extending up to $75 \mathrm{~m}(250 \mathrm{ft})$ downwind.

The abandoned-well blowout rate was calculated on a per well per year basis for all P\&A wells, and for P\&A wells residing in areas with and without steam injection. The number of P\&A wells residing in steam-injection areas was estimated by multiplying the total number of P\&A wells reported by California Division of Oil, Gas and Geothermal Resources (1992-2006), by the portion of total oil produced incrementally. The abandoned-well blowout rate was not calculated on a fluid volume basis, because estimates of the in-reservoir fluid volume change varied widely. This is because small variations in the assumed, inreservoir average steam mass fraction for injected steam/ water mixes result in large variations of the in-reservoir fluid volume change.

While it is unclear whether the in-reservoir fluid volumes in thermally enhanced recovery fields have increased or decreased on average across the district during the study period, steam is highly buoyant and moderately expansive. It will therefore migrate upward along available pathways whether the relative pressure, and fluid volume, in the reservoir is increasing or decreasing. Two approaches were applied, which together give end-member estimates of the area of District 4 with steam in the subsurface. The first approach assumes steam is present in the subsurface throughout the entire field area of any field with any steam injection. This is equivalent to the assumption that steaming occurs in one of many stacked pools, and this pool covers the entire field. The second approach assumes that the portion of the field with steam is equivalent to the portion of the field production wells influenced by steam. This approach, described in more detail in Appendix 2, is equivalent to the assumption that all production in a field is from a single pool only, and steam does not extend beyond the ring of wells closest to a steam-injection well, whether cyclic or flood.

Areas of the fields with steam injection were taken from California Division of Oil, Gas and Geothermal Resources (2006). The estimated end-member steam areas are 312 and $143 \mathrm{~km}^{2}$ (120 and $54 \mathrm{mi}^{2}$ ). Dividing the estimate of P\&A wells in thermally enhanced recovery areas by the end-member areas gives a well density between 75 and 163 P\&A wells per $\mathrm{km}^{2}$ (194 and 422 per $\mathrm{mi}^{2}$ ), or 0.75 and 1.6 P\&A wells per hectare (3.3 and 1.5 acres per P\&A well) in thermally enhanced recovery areas. This corresponds to an average P\&A well spacing

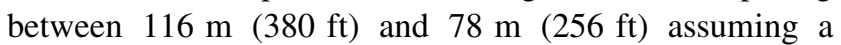
square well pattern.

"During other events" refers to two blowouts caused by events unrelated or marginally related to well operations. One of these occurred as a result of a motor vehicle 
Fig. $12 P$ values for blowout rate pairings within overall categories: a well construction, b well servicing, c operating wells, and $\mathbf{d}$ non-operating wells. The lower the $P$ value, the more likely the two blowout rates are statistically different. $P$ values below $5 \%$ are taken to indicate that the two blowout rates are fundamentally different. The lower, $0.3 \%$ threshold is explained in the text
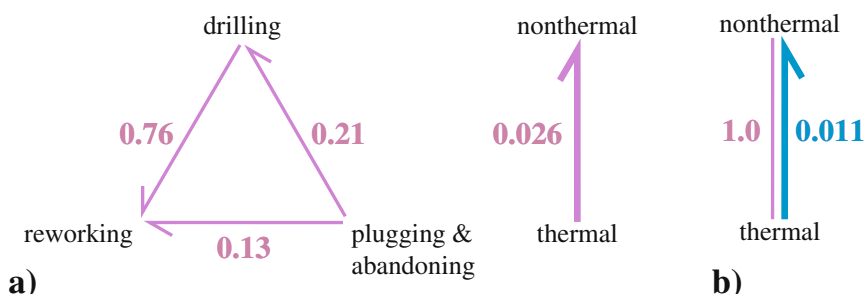

a)

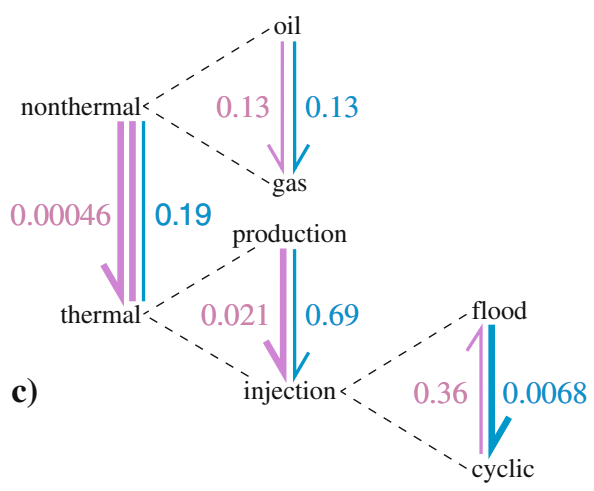

b)

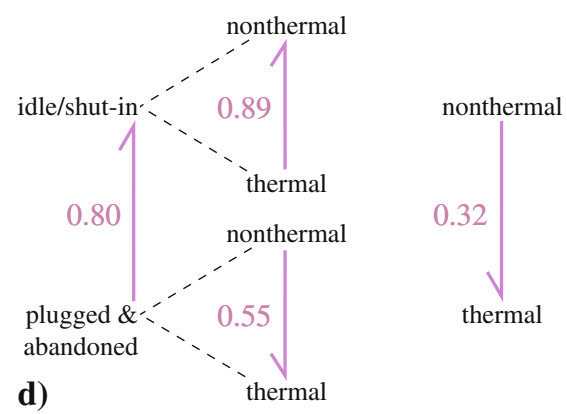

$p$-value legend

\begin{tabular}{cc||cc|}
$\begin{array}{c}\text { per well per year basis } \\
\text { greater than } 5 \%\end{array} \quad 0.76$ & $\mathbf{0 . 6 9}$ & per fluid volume basis \\
less than $5 \%$ & 0.021 & $\mathbf{0 . 0 1 1}$ & less than $5 \%$ \\
less than $0.3 \%$ & 0.00046 & $\begin{array}{l}\text { arrow points to } \\
\text { the higher rate }\end{array}$ \\
\hline
\end{tabular}

apparently hitting and damaging an idle well head. The other occurred when a production well head was damaged by a backhoe, presumably during field-related construction. Neither of these blowouts was included in any other category. The blowout rate due to these events was the lowest measurable of all the rates presented in this study on a perwell basis. This rate was not calculated on a fluid volume basis, because there is no genetic relation between fluid transferred by these wells and their likelihood of experiencing this type of blowout.

Data integrity and statistical significance

It is likely blowouts occurred during the study period that are not reflected in any of the four data sources used for this study. Nonetheless, two considerations suggest underreporting should not dramatically alter the findings of this study. First, Table 2 indicates over two-thirds of the known blowouts were recorded in more than one data source, so the number of unknown blowouts is probably significantly less than the number of known blowouts. Second, as mentioned, some of the blowouts from the ground surface away from a thermal injection well probably do not involve a well failure, and so are not technically well blowouts. Rather these blowouts occurred due to fluid migration from the reservoir to the ground surface along geologic pathways. As a result, the known blowout set used for the thermal injection well blowout rates is probably a bit inflated, somewhat compensating for the likely underreporting in this category.

Differences between the various blowout rates were tested for statistical significance using the following test statistic

$Z=\frac{r_{1}-r_{2}}{\sqrt{\mathrm{SE}_{1}^{2}+\mathrm{SE}_{2}^{2}}}$

where $r$ is the blowout rate and SE is the standard error of the blowout rate. SE was calculated by

$\mathrm{SE}=\frac{r}{\sqrt{n}}$

where $n$ is the number of (normalized) blowouts (Keyfitz 1966). $P$ values were looked up on a standard table for the calculated values of $Z$ (National Institute of Standards and Technology and SEMATECH 2008).

The $P$ values for different blowout rate pairs are shown in Fig. 12. Note that the upper limit blowout rate of 1 per 180,000 blowouts per plugged and abandoned well per year in non-thermal fields was used in the comparison of blowout rates in non-thermal and thermal fields. 
Two levels of significance are reflected in Fig. 12: a 5\% level and a $0.3 \%$ level. The $5 \%$ level is a common threshold of significance. The latter, quite stringent, significance level results from Bonferroni's correction, which calls for dividing the desired significance level, in this case $5 \%$, by the number of comparisons, in this case 18 . Bonferroni's correction seeks to preclude spurious findings of significance due to testing a large number of comparisons. Figure 12 shows that while the blowout rates from producing dry gas (meaning not associated with oil) wells are the highest of any well group, these rates are not significantly different from producing oil wells. This is due to the small number of dry gas wells (the basis for the rate) present in the district. The producing gas well blowout risks are not further considered in this study due to this small basis.

\section{Results and discussion}

A number of conclusions can be drawn from the findings above.

No public fatalities or injuries occurred as a result of the 102 blowouts studied. No worker fatalities or injuries occurred as a result of blowouts from operational, idle/ shut-in, or abandoned wells. One worker fatality and several worker injuries occurred during drilling, reworking, plugging and abandoning, and servicing operations combined. Four blowouts had an impact on the public, consisting of evacuation of and damage to a neighborhood, evacuation of a school, a power outage at one farm, and a few highway closures. Damage to the neighborhood was caused by deposition of oil dispersed as a mist.

There was, at most, only one abandoned-well blowout from a previously unknown or poorly located well. This is remarkable, given over a century of drilling and well construction in the district.

Low rates are observed from both abandoned wells and shut-in/idle wells. There is no significant difference between the rates from these wells, or between the rates in thermal versus non-thermal fields given the available data (see Fig. 12). This suggests shutting in a well is as effective as plugging it in terms of preventing blowouts.

The rate of blowouts from unknown and abandoned wells can reasonably be expected to have been higher during the early phases of thermally enhanced recovery, because these wells were first stressed by steam. Indeed, steam-injection volumes approximately tripled from the early 1970 s to the mid-1980s, when they peaked. Steaminjection volumes during the study period were relatively constant and averaged about three quarters of the mid1980s peak volume. Therefore a higher rate of blowouts from unknown and abandoned wells than observed during the study period might be expected prior to the mid-1980s. However, Hauser and Guerard (1993) list only two abandoned-well blowouts (in the mid-1980s) involving steam in the period from 1950 to 1990 , suggesting that similarly low blowout rates for these well types during the study period were not unusual.

Blowouts rates from operating wells in thermal fields are significantly higher than in non-thermal fields on a per well per year basis, even using the more stringent Bonferroni significance criteria, and blowout rates from producing wells are significantly greater than from injection wells in thermal fields on a per well per year basis (see Fig. 12). These rates are not significantly different on a fluid volume basis, however, despite the different types of fluids and fluid mixes involved (steam/water vs. water/steam/oil vs. water/oil). This suggests that fluid type and mix is not a fundamental determinant of blowout rates. Specifically, steam's oft-cited greater corrosivity and thermomechanical stress imposition appears not to actually cause significantly more blowouts per equal fluid volume transferred by the well. Rather, fluid volume, or some related parameter (such as pressure), is a fundamental determinant of blowout rates. Indeed, a sampling of well pressures from California Division of Oil, Gas and Geothermal Resources (2007) indicates that steam flood-injection wells had about three times the average well-head pressure as thermal area production wells, and they blew out about three times as often per well per year ( 1 per 7,100 vs. 23,000 wells per year). This finding suggests that steam-flood-injection wells blow out more frequently than other wells (on a per well basis) primarily because they operate at higher pressures, not because they transfer steam.

Well blowout rates per fluid volume are significantly higher for cyclic-steam wells than steam flood wells (see Fig. 12). This is probably primarily a result of the discontinuous fluid flow experienced by cyclic-steam wells. The discontinuous flow results in a lower fluid volume compared to the pressure imposed on these wells relative to steam flood wells.

The blowout rate per well per year for non-steam injection wells (less than 1 per 29,000) is about a fourth that for steam flood injection wells. The total fluid volume transferred by non-steam injection wells during the entire study period [1.2 billion $\mathrm{m}^{3}$ (7.8 billion bbl)] is less than one-fourth the fluid volume transferred per steam flood injection well blowout, though. These comparisons suggest that non-steam injection wells blew out less frequently than steam flood injection wells because they were generally operating at lower pressures, rather than due to fluid type or mix differences.

The drilling blowout rate of 1 per 1,900 borings in District 4 from 1991 to 2005 is virtually the same as the rate of 1 per 2,000 borings in California from 1950 to 1990 
(Hauser and Guerard 1993). The blowout risk during drilling and reworking are similar (approximately 1 per 1,800 operations) while that from plugging and abandoning is lower (1 per 3,400 operations), although not significantly so. While the latter has about the same chance of causing injury, it caused no environmental damage. As a consequence, the blowout risk during plugging and abandoning appears to be lower than during drilling and reworking, although the data used in this study are insufficient to show this statistically.

Blowouts from causes unrelated to the well (such as a motor vehicle hitting a wellhead) occurred at the extremely low rate of 1 per 380,000 wells per year.

The median blowout lasted $6 \mathrm{~h}$. The 95th percentile duration is 3.5 days. Around half of the blowouts emitted steam, oil and/or gas. Steam volumes emitted during these blowouts were not available, but the median oil and water volumes emitted were $0.05 \mathrm{~m}^{3}(0.33 \mathrm{bbl})$ and $0.3 \mathrm{~m}^{3}$ $(2 \mathrm{bbl})$, respectively. Around a quarter of the blowouts emitted gas and or earth (sand, mud, etc.). The median volumes emitted were $6 \mathrm{~m}^{3}$ (200 scf), and $0.035 \mathrm{~m}^{3}$ $\left(1.3 \mathrm{ft}^{3}\right)$, respectively. The distribution of volumes emitted during blowouts is long-tailed, however, so the 95th percentile volumes emitted range from one order of magnitude greater (for oil) to four orders of magnitude greater (for water and gas).

\section{Implications for geological storage of $\mathrm{CO}_{2}$}

The following paragraphs discuss implications of the well blowout statistics presented here for geological $\mathrm{CO}_{2}$-storage projects. This discussion is based upon an analogy between steam and $\mathrm{CO}_{2}$ injection, which is obviously an imperfect analogy. However, qualitative consideration suggests the analogy is sufficiently strong to allow drawing these implications. Steam is significantly more buoyant (lower density) than supercritical $\mathrm{CO}_{2}$. Steam injection depths are shallower than $\mathrm{CO}_{2}$-storage depths. Therefore steam injection areas in District 4 are likely to have older abandoned wells, and therefore a lower likelihood of well bore blockages sufficient to stop fluid flow from the reservoir up the well bore, than typical $\mathrm{CO}_{2}$-storage fields. Conversely, steam is less expansive than near-supercritical $\mathrm{CO}_{2}$, and steam can be quenched to a liquid as it migrates upward. Combining these countervailing considerations, the well blowout rates in District 4 areas with steam injection may not be significantly different from those in $\mathrm{CO}_{2}$-storage fields.

1. Blowouts in District 4 during field operation are rare events. In thermal-recovery fields, blowouts occur at an annual rate of 1 per 7,100 steam-flood injection wells, 1 per 130,000 idle/shut-in wells, and 1 per
98,000 P\&A wells. For a geological storage project in an area with wells of the same age distribution and depths, similarly low rates of blowouts would be anticipated. For a project with younger wells, lower blowout rates could be anticipated, with the caveat that well cement corrosion by $\mathrm{CO}_{2}$ may be greater or less than by steam.

2. Blowout rates declined dramatically over the 15 -year study period. The decline in total blowouts per year in District 4 is apparently a result of increasing experience, improved technology, and/or changes in safety culture in the oil and gas industry. This decline indicates that blowout rates in $\mathrm{CO}_{2}$-storage fields can be minimized, both initially and with increasing experience over time, if the $\mathrm{CO}_{2}$-storage industry is dedicated to the effort.

3. Data from District 4 suggest that blowout frequency increases with higher wellhead pressure. If this hypothesis is correct, then the blowout rate for $\mathrm{CO}_{2}-$ injection wells may be higher because the minimum wellhead pressure of $6 \mathrm{MPa}(870 \mathrm{psi})$ for $\mathrm{CO}_{2}$ injection is higher than the wellhead pressure of $3 \mathrm{MPa}$ (440 psi) for steam injection in District 4. Six MPa ( $870 \mathrm{psi})$ is just above the minimum liquid pressure for $\mathrm{CO}_{2}$ at $20^{\circ} \mathrm{C}\left(68^{\circ} \mathrm{F}\right)$. The minimum pressure increases with temperature. Carbon dioxide should be injected in the liquid or supercritical phase to prevent unstable phase transitions in the well bore, which would cause unstable injection pressures.

4. There were no injuries to the public. Only 4 of the 102 blowouts resulted in public impact, although it is worth noting the population density in District 4 is low, with most fields underlying population densities of 0 4 persons $/ \mathrm{km}^{2}$ (0-10 persons $/ \mathrm{mi}^{2}{ }^{2}$. The most severe long-term public impact consisted of the demolition and reconstruction of one partially constructed home and the filing of several lawsuits. This impact resulted from oil misting of a neighborhood, which is unlikely in $\mathrm{CO}_{2}$ blowouts.

5. Injuries to workers occurred in approximately $15 \%$ of the blowouts where workers were present (drilling, servicing, reworking, and plugging and abandoning). The extent to which worker injury rates caused by blowouts in geological storage projects will be the same as in District 4 is unknown, owing to the different nature of the hazards. Some of the hazards associated with blowouts in these different fields are similar-for example, injury from physical hazards such as tripping, falling and contusions. Other hazards are very different. The fire hazards from oil and gas well blowouts are not expected during $\mathrm{CO}_{2}$ blowouts. The large volume increase caused by the supercritical to gas transition as pressure drops is unique to $\mathrm{CO}_{2}$. 
Skinner (2003) notes that this expansion can cause supersonic exit velocities. It also causes cooling. This can cause formation of hazardous water ice and/or dry ice projectiles or snow from the well, and reduced visibility near the well resulting from water condensation in the atmosphere. Skinner (2003) reports these phenomena have made managing $\mathrm{CO}_{2}$ blowouts during $\mathrm{CO}_{2}$-EOR difficult using current techniques.

6. Approximately $75 \%$ of steam injection well and abandoned-well blowouts in thermal-recovery fields combined resulted in environmental damage. This damage was typically relatively minor, consisting primarily of earth displacement with a median volume of $2.3 \mathrm{~m}^{3}\left(81 \mathrm{ft}^{3}\right)$. A similar rate of environmental damage may be expected from $\mathrm{CO}_{2}$ blowouts.

7. The median blowout duration was $6 \mathrm{~h}$ and the 95th percentile duration was 3.5 days. Based upon the observations of Skinner (2003), $\mathrm{CO}_{2}$ blowout durations will likely be longer using current blowout control techniques. Blowout durations after storage-field closure will also likely be longer, owing to less intensive monitoring and ready response compared to operational oil fields. The number of such blowouts will be small, however, since all the storage-field wells will be plugged and abandoned or idle/shut-in at this time, and the reservoir pressure will be decreasing as a result of pressure dissipation, and/or $\mathrm{CO}_{2}$ dissolution and mineralization.

\section{Conclusions}

Data from 102 well blowouts between 1991 and 2005 in California Oil and Gas District 4 were analyzed. District 4 produced three quarters of the oil in the state, with the majority of this via thermally enhanced recovery using steam injection. The blowout occurrence and consequence rates and consequence types developed in this report for oil fields with thermally enhanced recovery can be used to inform risk assessments of well blowouts in $\mathrm{CO}_{2}$-storage projects. Appropriate caution should be used, however, because of the different thermomechanical stresses, blowout fluid compositions, and chemistry/phase effects in $\mathrm{CO}_{2}$-storage projects.

The frequency of blowouts in District 4 decreased dramatically during the study period. This decrease is not explained by a reduction in either total or per well fluid handling in the district. The most likely explanations are increased experience, improved technology, and/or changes in the safety culture in the oil and gas industry. Any of these explanations suggest that blowout risks can also be minimized in $\mathrm{CO}_{2}$-storage fields.
The blowouts analyzed did not cause any injuries to the public, but caused one worker fatality and several worker injuries. Impact to the public consisted of an evacuation and damage to a neighborhood, an evacuation of a school, a power outage at a farm, and three highway closures.

The blowout rate from abandoned wells in steam injection areas was quite low, at 1 per 98,000 P\&A wells per year. Consideration of $\mathrm{CO}_{2}$ versus steam injection suggests the abandoned-well blowout rate in $\mathrm{CO}_{2}$-storage fields may not be dissimilar. The abandoned-well blowout rate per area in thermal fields was estimated as between 0.00064 and 0.0014 blowouts per $\mathrm{km}^{2}$ per year $(0.0017$ and 0.004 blowouts per mi. ${ }^{2}$ per year) at a P\&A well density between 75 and 163 P\&A wells per $\mathrm{km}^{2}$ (194 and 422 per $\mathrm{mi}^{2}$ ), or between 0.75 and 1.6 P\&A wells per ha (3.3 and 1.5 acres per $\mathrm{P} \& \mathrm{~A}$ well). Blowout rates from shut-in/idle wells in thermal fields were also quite low, at 1 per 130,000 wells per year.

Blowouts occurred from 1 per 7,100 steam-flood injection wells in operation per year and 1 per 4,700 million $\mathrm{m}^{3}$ (30,000 million bbl) of fluid injected through these wells. More than half of these resulted in environmental damage, consisting of earth displacement due to blowouts meters to hundreds of meters away from the well head.

Half of the blowouts in steam injection areas took place when workers were on site during well drilling, reworking, servicing, or plugging and abandoning. A sixth of these caused injuries to workers, and a quarter damaged the environment. Blowouts occurred in 1 per 3,100 well drilling, reworking, and plugging and abandoning operations in steam injection areas, and 1 per 1,400 operations in nonthermal fields. Based on this comparison, along with worker injury severity, public impact, blowout fluid composition, quantity and duration, the blowout risk in thermal fields was significantly lower than in non-thermal fields.

Reservoir pressure will increase with time in $\mathrm{CO}_{2}$-storage fields during injection, as opposed to oil and gas fields where reservoir pressure tends to decrease with time during production. Considering this, and the lower overall rates in thermal fields, the drilling blowout rates in $\mathrm{CO}_{2}$-storage fields will likely be somewhat lower than the plugging and abandoning rates in District 4. Similarly, the plugging and abandoning blowout rates in $\mathrm{CO}_{2}$-storage fields will likely be somewhat lower than the drilling blowout rates in District 4.

The District 4 blowouts indicate operating pressure, rather than fluid type, is a primary, positively correlated parameter for per well per year blowout rates. Therefore, the downward trend in blowouts per year notwithstanding, and with all other conditions being equal, the data suggest that the $\mathrm{CO}_{2}$-injector blowout rate will be higher than the District 4 steam-flood-injector blowout rate per well per year, and the same or lower per-fluid volume. However, 
further studies of blowout rates in fields with significantly higher well pressures, flow rates, and $\mathrm{CO}_{2}$ injection are needed to check these conclusions. Obviously, similar studies in fields with $\mathrm{CO}_{2}$-EOR would be particularly useful for analyzing the effect of $\mathrm{CO}_{2}$ versus other fluid types. Similar studies in natural gas storage fields would offer perspective from yet another fluid type and set of pressure conditions. It might also be useful to study blowout rates in less rural areas to determine if the rates and consequences differ.

Acknowledgments We are grateful to Michael Stettner (Underground Injection Control Manager for DOGGR) for coordinating provision of the blowout data, and answering questions, Dave Mitchell (District 4 office) for supplying the digital blowout data, and Dan Tuttle and Mark Gamache (District 4 office) for answering questions, running queries, and supplying paper blowout record copies. We thank Estella Aguilar and Mary Fuller at the Bakersfield Californian for their patience in comprehending our request, subsequently diligently searching the newspaper's archives, and providing articles regarding blowouts in District 4. These articles were critical to increasing our confidence in the outcome of this study. We are also grateful to Alfredo Urdaneta (Aera Energy) for answering numerous questions about thermally enhanced production parameter values in general and in District 4. Michael Stettner and Dan Tuttle (DOGGR) kindly reviewed the paper, and Curt Oldenburg and Jens Birkholzer (LBNL) also provided valuable reviews (twice!). Jens's review in particular led to 1) the incorporation of more data streams in the analysis, and 2) the realization that well-head pressure, more than any other parameter, correlated with blowout rate. Comments from Sean Brennan, Environmental Geology's reviewer, led to the statistical analysis section, which significantly strengthened the paper. David Schlessinger, of Kaiser Permanente, kindly volunteered to advise us on this aspect of the paper. This said, the authors take full responsibility for the data analysis and conclusions.

This work was supported by the Assistant Secretary for Fossil Energy, Office of Coal and Power Systems, through the National Energy Technology Laboratory (NETL) under Department of Energy Contract No. DE-AC02-05CH11231.

\section{References}

Benson SM, Cook P, et al (2005) Underground geological storage. In: Freund $\mathrm{P}$, et al (eds) Intergovernmental panel on climate change special report on carbon dioxide capture and storage, Cambridge University Press, Cambridge, pp 195-276

California Department of Water Resources (undated) 1998 Kern County. http://www.landwateruse.water.ca.gov/basicdata/landuse/ counties/survey_years/vector_quads/98kn.cfm. Map without scale. Accessed 13 June 2007

California Division of Oil, Gas and Geothermal Resources (19922006) Annual report of the state oil and gas supervisor. Publication No. PR06, California Division of Oil, Gas, and Geothermal Resources, Sacramento

California Division of Oil, Gas and Geothermal Resources (2002) Kern County oil fields. ftp://ftp.consrv.ca.gov/pub/oil/maps/dist4/ Dist4_fields.pdf. Map scale approximately 1:9,200. Accessed 28 May 2005

California Division of Oil, Gas and Geothermal Resources (2006) Oil field data file dated 12/6/2006. ftp://ftp.consrv.ca.gov/pub/oil/ Data_Catalog/Oil_and_Gas/Oil_fields/CA_oilfields.DAT. Cited 13 June 2007

California Division of Oil, Gas and Geothermal Resources (2007), Monthly production and injection databases. http://www.consrv. ca.gov/dog/prod_injection_db/index.htm. Accessed 13 June 2007

Energy Information Administration (2007) Crude oil production. http://tonto.eia.doe.gov/dnav/pet/xls/pet_crd_crpdn_adc_mbbl_a. xls. Accessed 13 June 2007

Gasda SE, Bachu S, Celia MA (2004) Spatial characterization of the location of potentially leaky wells penetrating a deep saline aquifer in a mature sedimentary basin. Environ Geol 46(6-7): $707-720$

Hauser RL, Guerard Jr WF (1993) A history of oil- and gas-well blowouts in California, 1950-1990. Publication No. TR43, California Division of Oil, Gas, and Geothermal Resources, Sacramento

Kern Council of Governments (undated) Kern County, California, cities and census designate places, Census 2000. http://www. co.kern.ca.us/econdev/maps/city-cdp.pdf. Map scale approximately 1:53,000. Accessed 13 June 2007

Keyfitz N (1966) Sampling variance of standardized mortality rates. Hum Biol 38:309-317

National Institute of Standards and Technology and SEMATECH (2008) Engineering statistics handbook. http://www.itl.nist.gov/ div898/handbook/index.htm. Accessed 29 April 2008

Occupational Safety and Health Administration (2007), Oil and gas well drilling and servicing etool. http://www.osha.gov/SLTC/ etools/oilandgas/index.html. Accessed 13 June 2007

Schlumberger (2007) Oilfield glossary. http://www.glossary.oilfield. slb.com/default.cfm. Accessed 13 June 2007

Skinner L (2003) $\mathrm{CO}_{2}$ blowouts: an emerging problem. World Oil 224(1):38-42

San Joaquin Geological Society (2007) The history of the oil industry (with emphasis on California and Kern County). http://www. sjgs.com/history.html. Accessed 13 June 2007

Standing MB, Katz DL (1942) Density of natural gases. Trans AIME 146:141-149

United States Census Bureau (2007) American FactFinder. http://factfinder.census.gov/home/saff. Accessed 13 June 2007 